\title{
New Magnetic compilation and interpretation of the Bay of Biscay and surrounding continental shelves
}

\author{
Pauline Le Maire ${ }^{1, *}$, Isabelle Thinon ${ }^{1}\left(\mathbb{D}\right.$, Julie $_{\text {Tugend }}^{2,3}{ }^{(\mathbb{D}}$, Benoît Issautier ${ }^{1}$ (D), Guillaume Martelet $^{1}$ (D), \\ Fabien Paquet ${ }^{1}$, Jean-Noël Proust ${ }^{4}$ (D), Thierry Nalpas ${ }^{4}$, Aurélie Peyrefitte ${ }^{1}$ and Albane Canva ${ }^{5}$ \\ ${ }^{1}$ BRGM-French Geological Survey, Orléans, France \\ 2 Sorbonne Université, CNRS-INSU, Institut des Sciences de la Terre Paris, ISTeP UMR 7193, F-75005 Paris, France \\ ${ }^{3}$ CY Cergy Paris Université, GEC, F-95000 Cergy, France \\ ${ }^{4}$ Géosciences, Rennes, France \\ ${ }^{5}$ Géoazur CS 34229, Nice, France
}

Received: 15 December 2020 / Accepted: 11 October 2021 / Publishing online: 19 November 2021

\begin{abstract}
Producing accurate structural maps is a pre-requisite to unravel the tectonic evolution of a region. For this purpose, magnetic anomaly maps are helpful data sets for the identification and mapping of geological features. We compiled 154 marine surveys and 7 aeromagnetic campaigns covering the Bay of Biscay, its surrounding continental shelves and western part of the Pyrenees. As the initial data sets had heterogeneous acquisition parameters, we applied a series of transforms before merging the data. We performed a variable reduction to the pole to localize the extrema of the anomaly vertically to their causative sources and facilitate geological interpretations. The resulting intermediate resolution maps compiled at $500 \mathrm{~m}$ altitude offshore and $3000 \mathrm{~m}$ both on- and offshore, display magnetic trends and patterns. They are enhanced by several potential field operators (analytic signal, tilt angle, vertical derivative) enabling the interpretation of the geometry of the sources causing the anomaly $(3 \mathrm{D}, 2 \mathrm{D}$ and $2.5 \mathrm{D})$. The analysis of these magnetic maps allows us to precise the distribution and segmentation of crustal domains previously identified in the Bay of Biscay and its adjacent continental shelves. A series of crustal scale structures mapped onshore and formed during and after the Variscan orogeny show well on this new map compilation, allowing the continuous onshore-offshore mapping of some of them and revealing their role in segmenting the northern margin of the Bay of Biscay. This new compilation notably reveals variations in the magnetic signature of the Ocean-Continent-Transition (OCT) that we interpret as related to an increased magmatic production of the eastern part of the Bay of Biscay OCT during continental breakup. In addition to precise previous structural maps, this new magnetic compilation opens new perspectives for the interpretation of the Bay of Biscay geodynamic setting.
\end{abstract}

Keywords: magnetic compilation / aeromagnetic data / marine magnetic data / Bay of Biscay / passive margin segmentation / Ocean-Continent-Transition (OCT)

\section{Introduction}

Magnetic properties of rocks are used in different geological contexts to map structures, estimate the depth of magnetic sources, describe deformation patterns, or identify the limits of ancient terranes, among others. High-resolution magnetic grids are notably valuable to help in the production and interpretation of the compilation of structural maps, hence, to unravel the tectonic evolution of geological domains. However, prior to any modelling which can push the interpretation forward, we have to be sure that magnetic

*Corresponding author: pauline.lemaire3@gmail.com lineations are really related to a magnetic contrast and do not result from the processing and/or merging of data sets. This contribution presents a new magnetic map compiled from diverse aeromagnetic and shipborne surveys with the aim of providing the highest possible resolution on the Bay of BiscayWestern Pyrenees system (Fig. 1). Existing structural compilations of the Bay of Biscay and surrounding continental shelves (Fig. 1) are compared to our new magnetic compilation with the aim of guiding new regional tectonic interpretations. The Bay of Biscay-Western Pyrenees system is of particular geological interest because it underwent a succession of transcurrent, extensional and compressional tectonic events including the Variscan orogeny, the Permo-Mesozoic riftings, and the Pyrenean orogeny. This long tectonic history resulted 


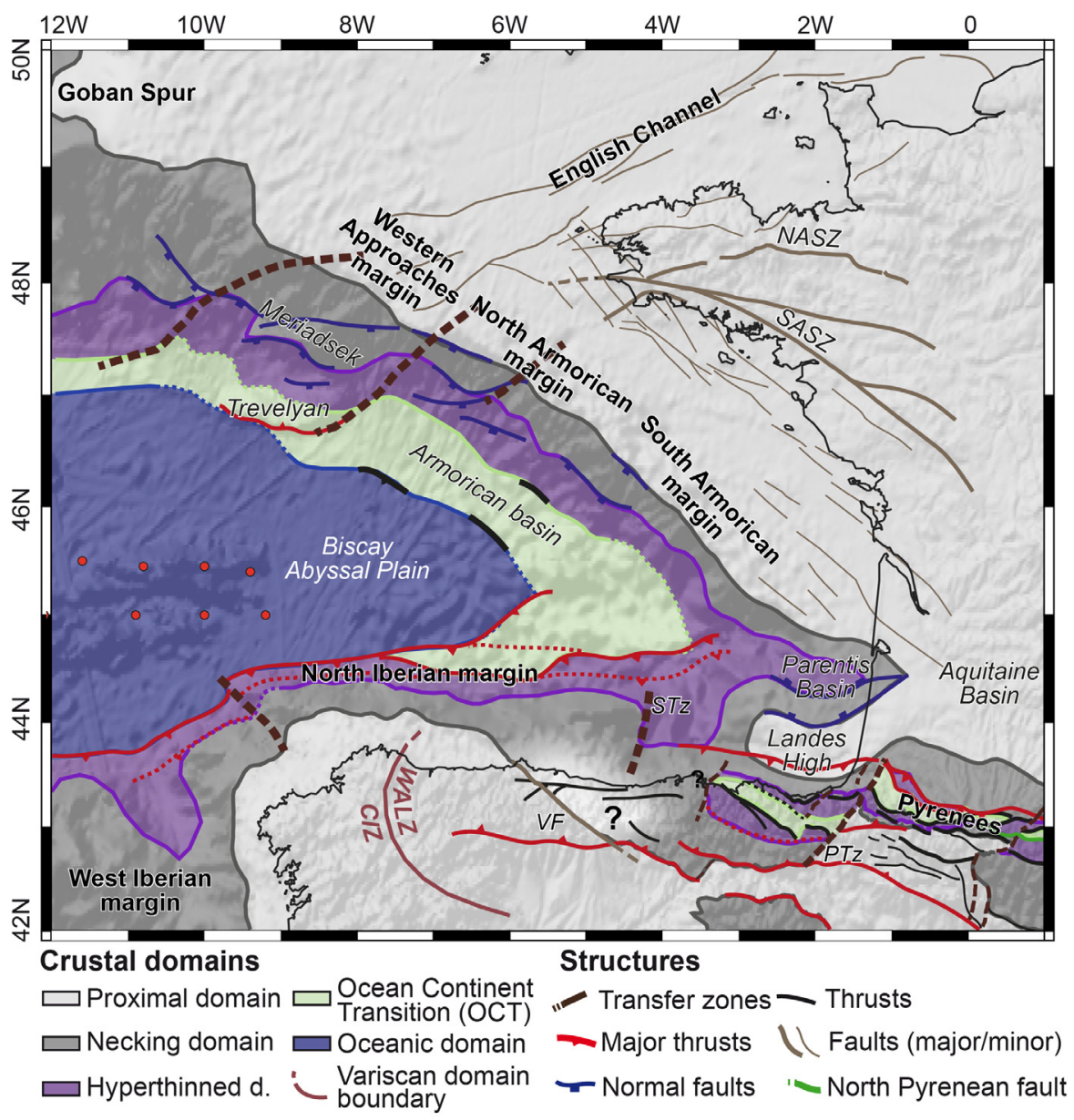

Fig. 1. Map of the rift domains preserved in the Bay of Biscay and their fossil analogues from the Pyrenean domain (after Tugend et al., 2014, 2015a including updates from Yang et al., 2020 towards Goban Spur and from Druet et al., 2018 and Cadenas et al., 2018 across the North Iberian Margin). The mapping of offshore structures is based on Thinon (1999), Thinon et al. (2003, 2009, 2018), Derégnaucourt and Boillot (1982) and Tugend et al. (2014). Aqui. M.: Aquitaine Margin; CIZ: Central Iberian Zone; WALZ: West Asturian-Leonese Zone; NASZ: North Armorican Shear Zone; SASZ: South Armorican Shear Zone; VF: Ventaniella Fault Zone; PTz: Pamplona Transfer Zone; STz: Santander Transfer Zone (from Roca et al., 2011). Red points correspond to the picking of marine magnetic anomalies A34y (Seton et al., 2014).

in the formation and reactivation of tectonic structures in different crustal domains previously distinguished based on their geological and geophysical signatures (Fig. 1, see Thinon et al., 2003, Tugend et al., 2015a for reviews).

Magnetic compilations which include the Bay of Biscay and surrounding shelves already exist (Verhoef et al., 1996; Lesur et al., 2016; Meyer et al., 2017), however, they were either of relatively low resolution or focused on offshore domains. In this contribution, we present new compilations at the altitudes of 500 and $3000 \mathrm{~m}$ including all available datasets both offshore and onshore to image with the highest possible resolution regional variations of the magnetic field. This new regional magnetic compilation allows us to assign a magnetic signature (characteristic intensity and texture) to the different crustal domains previously mapped (Fig. 1). Furthermore, the interpretation of magnetic anomalies allows us to confirm or remap the regional extent of several key crustal structures and evaluate their impact on the observed segmentation of the North Biscay passive margin.

\section{Geological setting and previous magnetic compilations}

\subsection{Geological setting}

2.1.1 Structure of the Bay of Biscay oceanic domains and its continental margins

The Bay of Biscay is a V-shape oceanic basin, which opened during the Cretaceous Magnetic Quiet Zone (CMQZ) between the European and Iberian lithospheric plates (Olivet, 1996; Sibuet et al., 2004). Compressional forces linked to the northward motion of Africa (Rosenbaum et al., 2002) inverted the North Iberian Margin to initiate a proto-subduction, during the Late Cretaceous (e.g., Boillot et al., 1979; Alvarez-Marron et al., 1997; Gallastegui et al., 2002; Tugend et al., 2014, 2015b; Pedreira et al., 2015; Cadenas et al., 2018, 2020). In contrast, the North Biscay Margin, which includes the Western Approaches and Armorican passive margin segments (Fig. 1, Thinon et al., 2003) and its continental shelf were weakly 
deformed, and the passive margin architecture is preserved (Barbier et al., 1986; Thinon et al., 2001; Tugend et al., 2014). The distribution of oceanic and continental crustal domains and in-between Ocean-Continent Transition (OCT) has previously been identified and mapped from the Bay of Biscay to its adjacent offshore continuation now integrated in the Pyrenees (Fig. 1, Thinon et al., 2003; Roca et al., 2011; Tugend et al., 2014; Ruiz et al., 2017; Cadenas et al., 2018).

The Bay of Biscay oceanic domain is interpreted to have developed during a short-lived late Early Cretaceous (AptianAlbian) to Late Cretaceous (84 Ma, Santonian) seafloor spreading episode (e.g., Bacon et al., 1969; Montadert et al., 1979; Boillot, 1984; Sibuet and Collette, 1991; Sibuet et al., 2004; Tugend et al., 2015b; Barnett-Moore et al., 2016, 2017; Nirrengarten et al., 2018). This interpretation is mainly deduced from the identification of magnetic anomalies in the North Atlantic Ocean and their interpreted continuation in the Bay of Biscay. A strong linear magnetic anomaly has previously been identified in the central part of the Biscay abyssal plain (e.g., Williams, 1975; Cande and Kristoffersen, 1977; Srivastava et al., 1990; Olivet, 1996; Sibuet et al., 2004) and interpreted as produced during Chron 34, dating the end of oceanic accretion during the Late Cretaceous ( $~ 84 \mathrm{Ma}$; Montadert et al., 1979). Anomaly 34 young is interpreted as the magnetic signature of the fossil-spreading axis located close to basaltic rocks drilled at Deep Sea Drilling Project Site 118 (Laughton et al., 1972a, 1972b). At the foot of the Goban Spur Margin (westernmost extremity of the Bay of Biscay, Fig. 1), DSDP site 550 (Leg 80; Graciansky and Poag, 1981) dated the first oceanic crust to Early Albian time. In the Bay of Biscay, however, the age of the onset of oceanic accretion cannot be ascertained using oceanic magnetic anomalies. Some of the magnetic anomalies occurring along the OCT of the Bay of Biscay rifted margins have been interpreted as seafloor spreading anomalies from the M-series (Sibuet et al., 2004) analogous to those interpreted along the West Iberia Margin (Srivastava et al., 2000). Onset of oceanic accretion in the Bay of Biscay has been interpreted as occurring either prior to (Srivastava et al., 1990; Sibuet and Collette, 1991), during (Montadert et al., 1979; Boillot, 1984; Sibuet and Collette, 1991; Thinon et al., 2003; Sibuet et al., 2004) or just after (Montadert et al., 1979; Thinon et al., 2003) the M0 anomaly ( $125 \mathrm{Ma}$, Gee and Kent, 2007). However, the interpretation of these magnetic anomalies as seafloor spreading anomalies is debated both in the Bay of Biscay (Thinon et al., 2003) and along the West Iberian and Newfoundland rifted margins (Nirrengarten et al., 2017), casting doubts on the age of the onset oceanic accretion.

Located in between the oceanic and hyper-thinned continental domains, a wide OCT has previously been mapped along the North Biscay passive margin (including the $\sim 80 \mathrm{~km}$-wide Armorican Basin, Thinon et al., 2003), and in the abyssal plain at toe of the Aquitaine Margin (Fig. 1; Roca et al., 2011; Tugend et al., 2014; Ruiz et al., 2017). The Bay Biscay OCT is now interpreted by most authors as floored by exhumed mantle, more or less serpentinized and associated with more or less mafic magmatism, based on seismic and gravity data (Fig. 1; e.g., Thinon et al., 2003; Roca et al., 2011; Tugend et al., 2014; 2015a; Ruiz et al., 2017). Stratigraphic correlations conducted along the Western Approach Margin (Thinon et al., 2002) suggest that the OCT formed at the end of the rifting by Aptian-Albian time (Thinon et al., 2003).

\subsubsection{The continental shelves}

The structural framework of the English Channel, Western Approaches, and Armorican continental shelf (Fig. 1) is relatively well known, constrained by different data sets (field work, seismic data, magnetic data), previously synthesized in geological maps (Lefort et al., 1997; Chantraine et al., 2003).

The English Channel includes a succession of PermoTriassic to Early Jurassic Basins oriented WSW-ENE (e.g., Evans, 1990), setting up on a Paleozoic basement previously affected by the Variscan orogeny (Early Carboniferous; Ziegler, 1987; Matte, 2001; Ballèvre et al., 2014; and references therein), being located in the outer part of the Ibero-Armorican Arc (Matte and Ribeiro, 1975; Ballèvre et al., 2014; Cochelin et al., 2017, Authemayou et al., 2019 and references therein). The English Channel has been reactivated during the Pyrenean orogeny (e.g., Evans, 1990; Le Roy et al., 2011).

The Armorican continental shelf is characterized by a $30-\mathrm{km}$ thick crust including various outcropping lithologies (granites, metasediments, high pressure units), mainly inherited from the Variscan orogeny (e.g., Chantraine et al., 2003; Ballèvre et al., 2014). The structural pattern of the Armorican shelf is characterised by large-scale WNW-ESE to NW-SE trending transcurrent fault systems, alike the South Armorican Shear Zone (SASZ) in the Armorican Massif (e.g., Chantraine et al., 2003; Guillocheau et al., 2003; Thinon et al., 2009, 2018; Paquet et al., 2010). Outcrops of Variscan basement are frequent along the inner part of the Armorican shelf, however, thick Mesozoic and/or Tertiary sediments cover the outer part of the North Biscay and Aquitaine shelves. As a result, the main crustal structures of the inner Armorican shelf along the south Brittany and Charente coast are well known and mapped (e.g., Chantraine et al., 2003; Thinon et al., 2009, 2018; Paquet et al., 2010), in contrast to the structure of the outer part of the shelf (Fig. 1).

The Aquitaine shelf includes the E-W trending Parentis Basin delimited to the South by the Paleozoic basement of the Landes High (Fig. 1). As imaged by seismic data and calibrated by drilling results, the Parentis Basin is a thick asymmetric Mesozoic-Cenozoic Basin (up to $15 \mathrm{~km}$ thick, e.g., Bois et al., 1997; Biteau et al., 2006; Tugend et al., 2014, 2015a) sitting on highly thinned continental crust (locally less than $10 \mathrm{~km}$ thick, Bois et al., 1997; Tugend et al., 2015a). The stratigraphic architecture of rift sequences is largely controlled by the occurrence of the thick Triassic salt layer (Ferrer et al., 2009; Jammes et al., 2010a; Lagabrielle et al., 2019) allowing the decoupling of deformation between supra-salt formations and the underlying basement (as shown in the analogous Columbrets Basin, Etheve et al., 2018). The Parentis Basin is bounded to the South by one or several normal faults (e.g., Ferrer et al., 2008; Jammes et al., 2010a; Tugend et al., 2015a) that controlled the observed crustal thinning interpreted as resulting in metamorphism and magmatism (Bois et al., 1997). Based on the interpretation of ECORS seismic profiles, several authors suggested that the Cretaceous rifting of the Parentis Basin was largely controlled by the Variscan tectonic framework of the Paleozoic basement (e.g., Bois et al., 1997, Gariel et al., 1997). The Landes High, located between the Parentis Basin and the onshore Basque-Cantabrian Basin, corresponds to a relatively weakly thinned continental block 


\section{GAMMAA5}
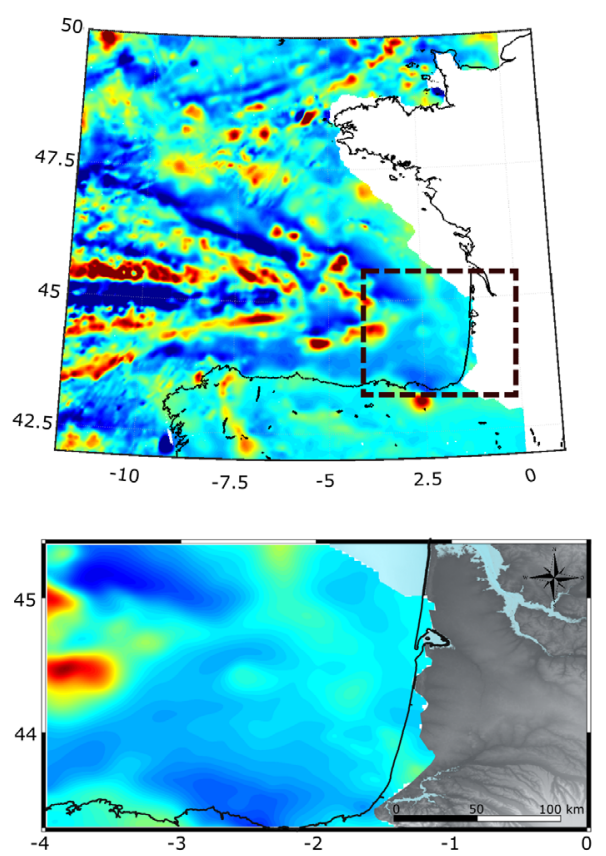

WDMAM $_{\mathbf{V} 2}$

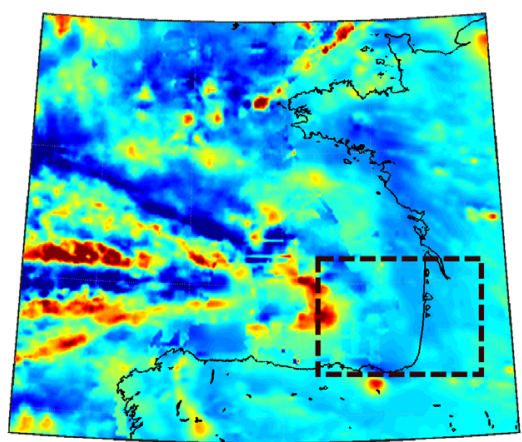

EMAG2 $_{\mathrm{v} 3}$

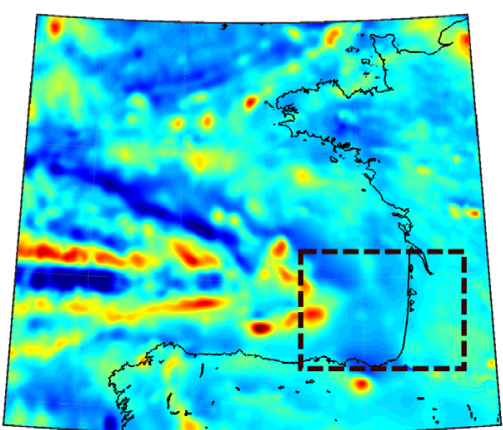

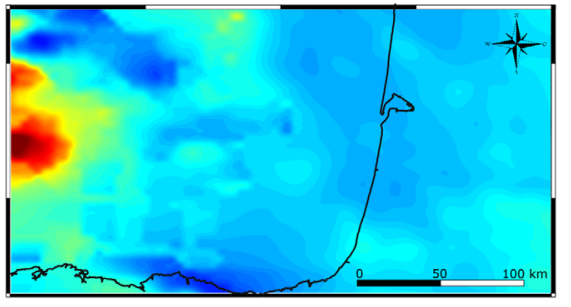

nT

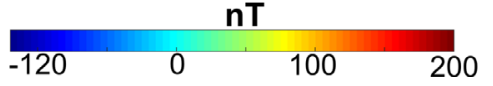

Fig. 2. Total field magnetic anomaly maps of previous compilations (GAMMAA5, WDMAMv2 and EMAG2V3-plotted with the same color scale). The upper panel present the three grids for the Bay of Biscay domain and the lower panel a zoom over the Landes-Parentis area.

(Bois et al., 1997; Roca et al., 2011; Tugend et al., 2014). Only the uppermost part has been sampled and included clays and magmatic rocks like ophites under the thin Upper CretaceousTriassic sedimentary cover (Danu and Taramis wells). The southern part of the Meso-Cenozoic cover is affected by the North-Pyrenean Frontal Thrust system (e.g., Ferrer et al., 2008).

The North-Iberian shelf that borders the Bay of Biscay to the South is narrower than the Armorican continental shelf and its structure varies from west to east. Onshore of the northern Iberian shelf, a large part of the outcropping rocks emplaced prior to, during or subsequently to the Variscan history with different Variscan domains being distinguished. Of particular interest is the boundary between the Central Iberian Zone (CIZ) and the West Asturian-Leonese Zone (WALZ), which is marked by a set of magnetic anomalies (Fig. 1; Ayarza et al., 2004). To the west, the North-Iberian shelf is characterized by a $\sim 30 \mathrm{~km}$ thick crust imaged along the IAM 12 refraction profile (Alvarez-Marron et al., 1997; Fernandez-Viejo et al., 1998) and segmented by a series of NW-SE transfer faults (Derégnaucourt and Boillot, 1982). To the east, the northern Iberian shelf hosts the thick Early Cretaceous Asturian Basin delimiting the narrow Le Danois Bank from the main shelf to the south (Gallastegui et al., 2002; Cadenas et al., 2018). The structure changes again east of the Torrelavega and Santander canyons (Pedreira et al., 2007), interpreted as bounding a N-S to NNE-SSW soft transfer zone formed during the Early Cretaceous rifting and subsequently reactivated during the orogeny (Roca et al., 2011). Despite the identification of rift related structures and basins (e.g., Cadenas et al., 2018), the present-day morphology of the North-Iberian shelf is largely controlled by the inversion and partial under-thrusting of the Bay of Biscay distal margin and oceanic domain below the Iberian plate during the Pyrenean orogeny (Figs. 1; e.g., Boillot et al., 1979; Alvarez-Marron et al., 1997; Gallastegui et al., 2002; Roca et al., 2011; Pedreira et al., 2015).

\subsubsection{Pyrenees Domain}

Inland, the northern edge of the Aquitaine Foreland Basin (Charentes region) formed over a Palaeozoic basement whose structuring, likely complex, is difficult to constrain, since it is not exposed. Nevertheless, two different geological features have previously been identified and interpreted (Montigny and Allegre, 1974; Maillet, 1977; Santallier, 1981; Mercier et al., 1985; Triboulet and Audren, 1985; Girardeau et al., 1986; Lefort et al., 1997): (i) a NW-SE Carboniferous Basin called the Saintes-Cognac Graben; and (ii) N140-oriented band of Late Proterozoic to Early Paleozoic mafic/ultramafic rocks. Further to the south, the Pyrenean-Aquitaine structural framework is characterized by the occurrence of several crustal to lithospheric scale structures, most of which are interpreted as inherited from the Variscan orogeny. They correspond to $\sim \mathrm{N} 110$ trending structures including the «Flexure Celtaquitaine» (BRGM et al., 1974). This structure is interpreted as a major Variscan Thrust complex in between pre-Variscan metasediments and Carboniferous Basins (Lefort et al., 1997; Rolet, 1997). Its geometry is poorly constrained and different mapping have been proposed (BRGM et al., 1974; 
Table 1. Main characteristics of the dataset covering the Bay of Biscay and surrounding continental shelves.

\begin{tabular}{|c|c|c|c|c|c|c|c|}
\hline & Year & Survey name & Operator & Reference code & $\begin{array}{l}\text { Sensor elevation } \\
(\mathrm{m})\end{array}$ & $\begin{array}{l}\text { Line spacing } \\
(\mathrm{km})\end{array}$ & Strategies to compute map at $500 \mathrm{~m}$ \\
\hline 1 & 1962 & Lands & Shell & 1014 & 610 & 2 & Downward continuation \\
\hline 3 & 1966 & Plateau continental Atlantique & Shell & 2502 & 500 & 4 & - \\
\hline 4 & 1968 & Sud Gascogne sud & ESSO & 2577 & 1500 & 8 & Equivalent layer \\
\hline 7 & 1983 & Sud Aquitaine & ESSO & 6200 & 780 & $1.2 / 3.6$ & Downward continuation \\
\hline 8 & & 156 marine surveys & & & 0 & & Upward continuation \\
\hline
\end{tabular}

Lefort et al., 1997; Rolet, 1997; Serrano et al., 2006). N110 trending structures such as Audignon, Antin-Maubourguet and Percorade ridges are salt tectonic structures formerly interpreted as Albian-Cenomanian in age (Mauriaud, 1987; Serrano et al., 2006), and recently reinterpreted as already initiated during the Late Triassic-Hettangian rifting stage (Issautier et al., 2020).

A second set of structures trends in a N20 to NE-SW direction, like for instance the Pamplona and ToulouseVillefranche faults (e.g., Razin, 1989; Rolet 1997; Larrasoaña et al., 2003). These structures are believed to strongly control both the segmentation of the Early Cretaceous Rift Basins and their subsequent inversion initiated in the Late Cretaceous (Pedreira et al., 2007; Roca et al., 2011; Tugend et al., 2014, 2015b; Canérot, 2017; Saspiturry et al., 2019; Issautier et al., 2020; Ducoux et al., 2021; Lehujeur et al., this volume). Some of these are interpreted as partly inherited from the Late Variscan stage and/or Triassic-Hettangian rifting (Serrano et al., 2006; Tugend et al., 2014; Saspiturry et al., 2019; Issautier et al., 2020). Due to their successive reactivations, the geometry of these structures is not always clear. Our knowledge is mainly derived from sub-surface observations, provided by field data, drillholes, or seismic data and the indepth extent of these structures and their impact on different crustal domains are sometimes unknown, imprecise or debated.

\subsection{Previous magnetic compilations}

Three published magnetic compilations cover the Bay of Biscay and the western part of the Aquitaine Basin (including the Parentis Basin and Landes High areas) (Fig. 2). The Grid Aeromagnetic and Marine Magnetics of the north Atlantic and Artic (GAMMAA5) is a compilation from marine and airborne magnetic surveys with a grid resolution of $5 \mathrm{~km}$ and without corrections for the non-uniform altitude of the observation points (Verhoef et al., 1996). The World Digital Magnetic Anomaly Map(WDMAMv2) (Lesur et al., 2016) also compiled marine magnetic campaigns and aeromagnetic surveys. The resolution of the grid is 3 arc minutes for an altitude of $5 \mathrm{~km}$ above continental areas and at sea level for marine areas. The Earth Magnetic Anomaly Grid(EMAG2v3) compiled satellite, marine and airborne magnetic surveys with a 2 arc min resolution at $4 \mathrm{~km}$ altitude (Maus et al., 2009; Meyer et al., 2017).
The result of these previous compilations is shown in Figure 2 for the Bay of Biscay domain and Landes-Parentis subset area. The GAMMAA5 compilation has a slightly higher resolution but there are no data onshore. WDMAM has a good resolution both offshore and onshore but shows visible artefacts, which are probably due to the merge of data sets with different resolutions. The EMAG2v3 compilation has no obvious artefacts but, as the compilation was made at $4 \mathrm{~km}$ above the sea level, the anomalies are smoothed, removing the high frequency content which bears crucial information to map structural domains. Therefore, it appears that none of these existing compilations are suitable to perform a comprehensive intermediate resolution onshore-offshore geophysical characterisation and geological interpretation of the rifted margins of the Bay of Biscay.

\section{New magnetic compilation}

\subsection{Datasets}

We used $104700 \mathrm{~km}$ of marine profiles and seven aeromagnetic surveys (Fig. 3) acquired by industrial and academic partners in the sixties and eighties (Tab. 1). Given their age, the nature of available data is very different, including raw data, grids and paper maps.

\subsubsection{Marine magnetic data}

Various institutions and ships acquired the marine data used in the compilation. Magnetic data have been extracted from the world data service for Geophysics (https://www.ngdc. noaa.gov/mgg/mggd.html) and the French National Oceanographic Data Centre (SISMER). We added two campaigns: ZEE GASCOGNE (Pautot, 1992) and ZEEGASC2 (Le Suave, 1997). In total, 156 marine magnetic campaigns and $104700 \mathrm{~km}$ are integrated in our study (Fig. 3).

\subsubsection{Aeromagnetic data}

The compilation also integrates seven aeromagnetic surveys acquired between 1962 and 1983 by SHELL, ESSO and the Institut de Physique du Globe de Paris (IPGP) (Le Borgne et al., 1971). The two first surveys (Tab. 1, 1-2) were acquired with a fluxgate magnetometer and the other ones used an absolute cesium-vapor optically pumped magnetometer. The spacing between the lines is highly variable, ranging from 


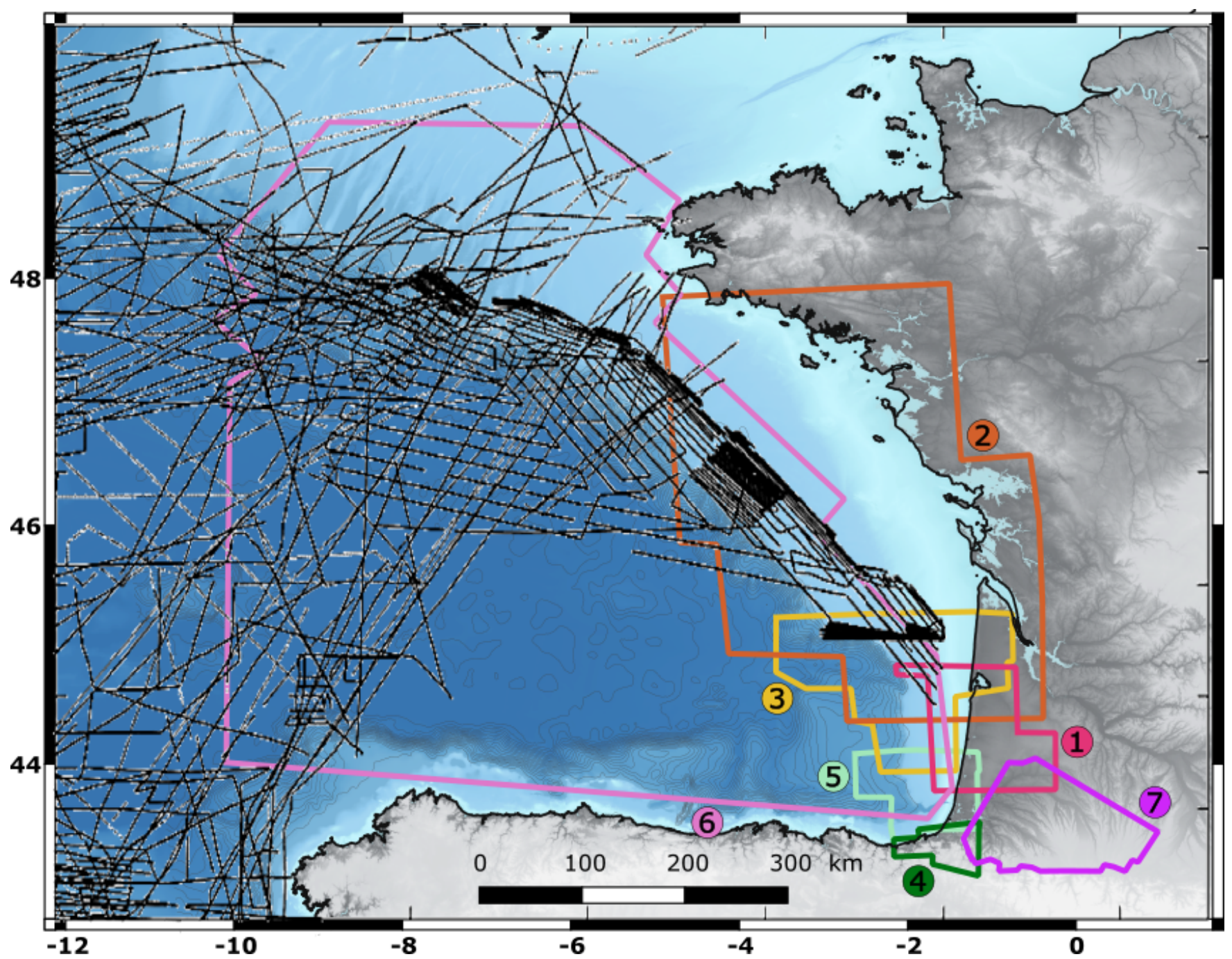

Fig. 3. Marine magnetic track lines (in black) and limits of the seven aeromagnetic surveys (coloured polygons) whose label numbers refer to Table 1.

1.2 to $20 \mathrm{~km}$ and the altitudes of the surveys range from 500 to $1500 \mathrm{~m}$ (See Tab. 1 for acquisition parameter of each survey). The first six surveys were available as paper maps only.

Each dataset required its specific processing to homogenize the data and prepare it for the compilation. The processing was performed with the Applimag Software (Matlab codes developed by M. Munschy at the Institut Terre et Environment de Strasbourg).

\subsubsection{Processing of the datasets}

For marine datasets, a manual selection of 707 profiles with magnetic data was made. Then, the regional field of the year of the survey was substracted from each dataset using the IGRF12 model (Thébault et al., 2015). To minimize the errors in the dataset, we applied the same strategy that on the airborne dataset: Levelling. For the levelling correction, first, the crossover points are measured (3727 crossing points, for 707 profiles). Next, the differences at crossover points between two profiles are computed. Lastly, a constant applied to each profile is determined by a linear inversion to minimize the differences at the crossover points (Luyendyk, 1997). The standard deviation of the crossovers was reduced from $45.7 \mathrm{nT}$ to $28.1 \mathrm{nT}$ by the levelling. Lastly, the overall dataset was interpolated on a grid of $500 \mathrm{~m}$ cell size using a gradient method algorithm (D’Errico, 2006).

For the aeromagnetic datasets, six of the seven surveys were only available as magnetic isolines on paper maps. These maps were georeferenced and digitized in a GIS, carefully checked and gridded (D'Errico, 2006).

To restore each grid at an altitude of $500 \mathrm{~m}$, we applied two strategies for the 5 grids which were initially not at this elevation: upward/downward continuation (Baranov, 1957) and equivalent layer (Dampney, 1969). The first method transforms the magnetic grid (at altitude $h$ ) in the wavenumber domain and applies an operator of continuation to another altitude $h+s_{0}$.

$$
F\left(u, v, h+s_{0}\right)=F\left(u, v, s_{0}\right) e^{-\sqrt{u^{2}+v^{2} z}}
$$



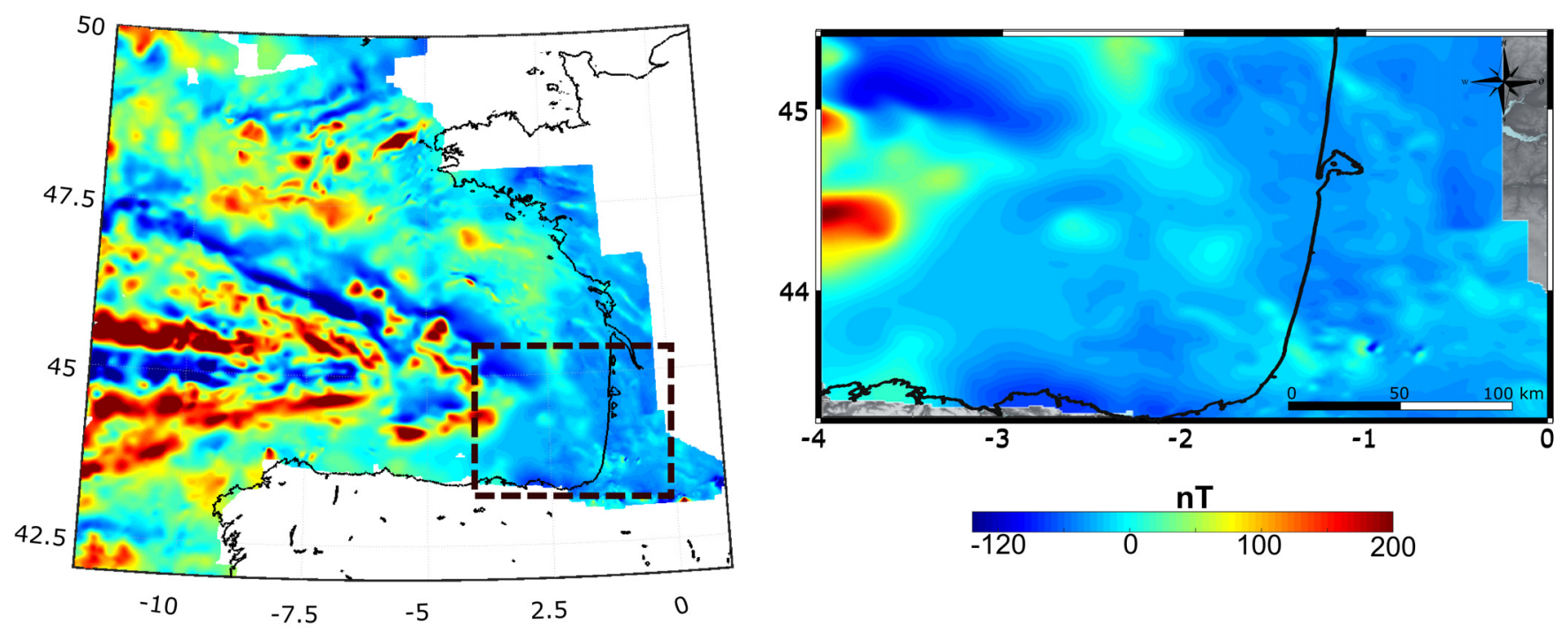

Fig. 4. The new magnetic compilation map at $500 \mathrm{~m}$ of the Bay of Biscay (left side). Zoom on the Landes-Parentis area (right side).

with $u$ and $v$, being the spatial frequencies in the north and east directions and $z$, the altitude of the survey. For the downward continuation, $\mathrm{z}$ is negative and this operator increases the amplitude of the high frequencies and rapidly becomes unstable. For survey 4 (Sud Gascogne Sud), the distance between the two surfaces is equal to $1000 \mathrm{~m}$, so an equivalent approach was privileged. In order to derive the equivalent source magnetization from the initial magnetic grid a zerothorder Tikhonov regularization was applied (Tikhonov and Arsenin, 1977; Oliveira et al., 2013, Eq. (4)):

$$
p=G^{T}\left(G G^{T}+\mu I\right)^{-1} d
$$

where $\mathrm{p}$ is the magnetic property of the equivalent source, $\mathrm{G}$ is the matrix of Green's functions, $\mu$ is a regularizing parameter, and $\mathrm{I}$ is an identity matrix and $\mathrm{d}$ is the magnetic observations. A source depth of $3500 \mathrm{~m}$ and source spacing of $1000 \mathrm{~m}$ was used.

\subsubsection{Compilation procedures}

The merging of the 8 resulting grids ( 7 for the aeromagnetic datasets and 1 for the compilation of the 154 marine magnetic datasets) at an altitude of $500 \mathrm{~m}$ was computed with the suturing tool GridKnit (Geosoft, 2013). The "suture" method was used to stitch the grids together. Figure 4 displays the result of the merge of all datasets at an altitude of $500 \mathrm{~m}$. In the Landes-Parentis area, this compilation has a higher resolution than previous magnetic compilations (Fig. 2), but the anomalies in continental areas (Spain and France) are not complete.

The Bay of Biscay compilation was continued upward from the altitude of 500 to $3000 \mathrm{~m}$. A second magnetic compilation was computed at an altitude of $3000 \mathrm{~m}$ (Fig. 5) merging our compilation with the magnetic map of Spain (Ardizone et al., 1989) and the magnetic map of France (Le Borgne and Le Mouël, 1969).

\subsubsection{Potential field transforms}

To help geological interpretations, the compilation of magnetic grids was reduced to the pole. This operation compensates the skewness of magnetic anomalies and enables the extrema value to be located vertically to their causative sources-as far as their magnetization is mainly induced (Fig. 6). The study area is large $\left(>500 \mathrm{~km}^{2}\right)$, so a variable reduction to the pole was computed (Cooper and Cowan, 2005) in order to take into account the variations of orientation of the regional magnetic field.

Three transforms were applied to the anomalies reduced to the pole: the analytic signal, the tilt angle and the first order vertical derivative (Fig. 7).

The analytic signal or total gradient of the anomaly is used to locate 3D magnetic bodies like intrusions for example; it has the property to locate the anomalies vertically to the causative sources whatever the type of magnetization of the source (induced or remanent). The analytic signal (Roest et al., 1992) is expressed as:

$$
\begin{gathered}
S A(x, y, z)=\sqrt{\left(\frac{\partial T(x, y, z)}{\partial x}\right)^{2}+\left(\frac{\partial T(x, y, z)}{\partial y}\right)^{2}} \\
+\left(\frac{\partial T(x, y, z)}{\partial z}\right)^{2}
\end{gathered}
$$

with $\frac{\partial T(x, y, z)}{\partial x}, \frac{\partial T(x, y, z)}{\partial y}, \frac{\partial T(x, y, z)}{\partial z}$, being the partial derivatives of the grid in the $\mathrm{x}, \mathrm{y}$ and $\mathrm{z}$ directions.

The tilt angle is efficient for structural interpretation as it allows the mapping of both strong and weak contrasts of magnetization. It is written as (Miller and Singh, 1994):

$$
\operatorname{Tilt}(x, y, z)=\tan ^{-1}\left(\frac{\frac{\partial T(x, y, z)}{\partial z}}{\sqrt{\left(\frac{\partial T(x, y, z)}{\partial x}\right)^{2}+\left(\frac{\partial T(x, y, z)}{\partial y}\right)^{2}}}\right) .
$$

The first vertical derivative is used to localise the edge of magnetic bodies. This transformation removes long wavelength anomalies and highlight shallow structures.

$$
D V(x, y, z)=\frac{\partial T(x, y, z)}{\partial z}
$$



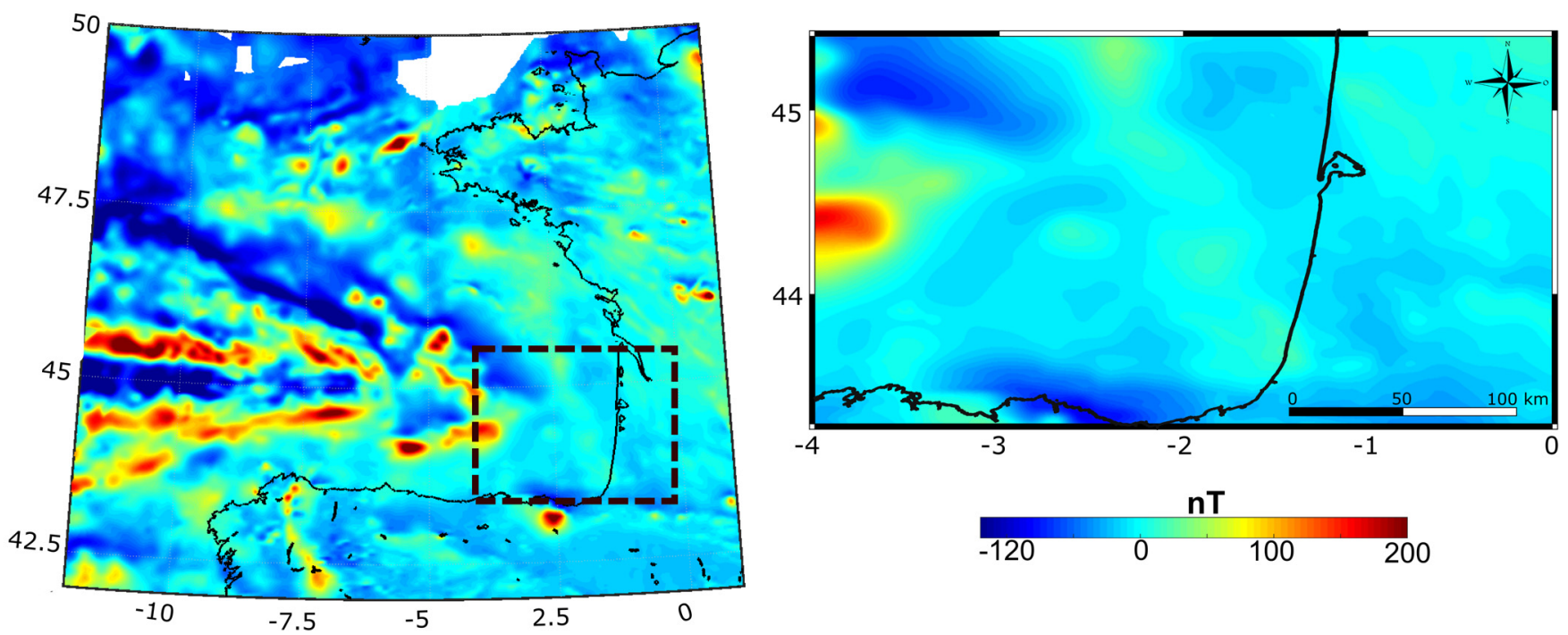

Fig. 5. The new magnetic compilation map at $3000 \mathrm{~m}$ of the Bay of Biscay (left side). Zoom on the Landes-Parentis area (right side).
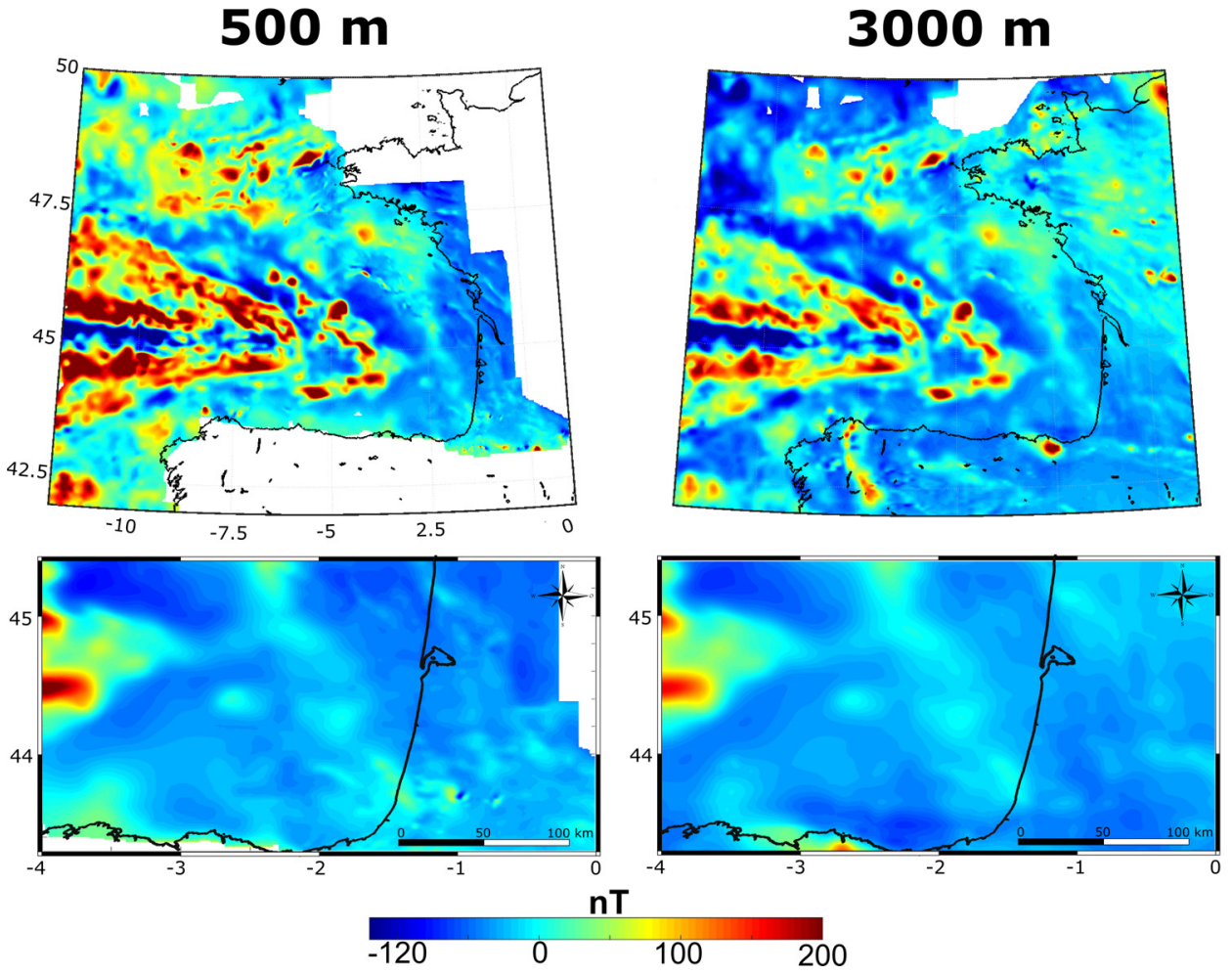

Fig. 6. Reduction to the pole applied to the total magnetic intensity maps at $500 \mathrm{~m}$ and $3000 \mathrm{~m}$ of the Bay of Biscay and encompassing continental areas. The lower panel shows a zoom over the Landes-Parentis area. 

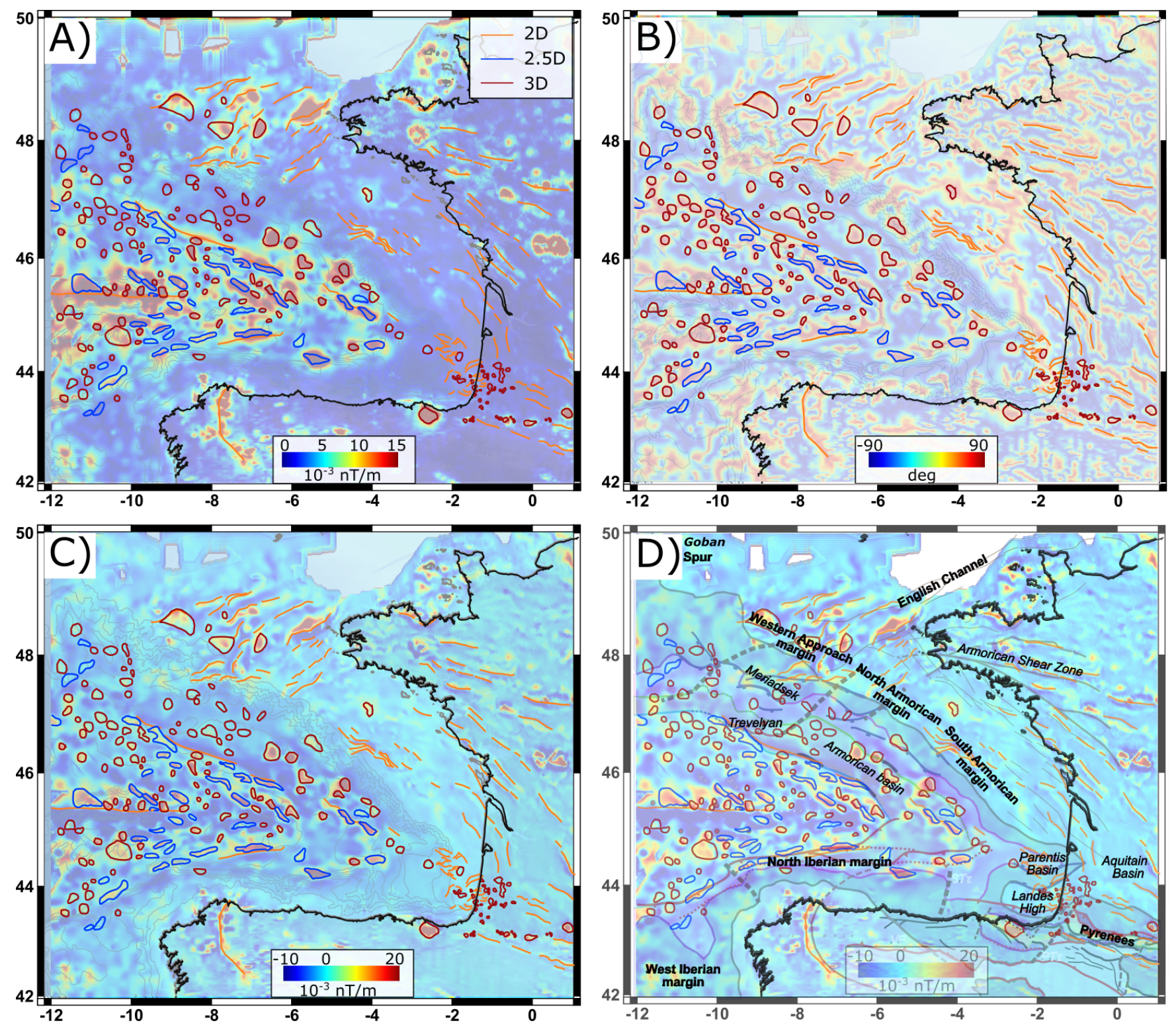

Fig. 7. (A) Analytic signal magnetic map after RTP. (B) Tilt angle magnetic map after RTP. (C) Vertical derivative magnetic map after RTP. (D) Magnetic interpretation on the vertical derivative map with Figure 1 in the background.

\section{Results and interpretations}

\subsection{Magnetic interpretation: synthetic cases}

To help the interpretation of the compilation maps, we characterized the magnetic anomalies according to three types of potential field source geometries: 3D (close to spherical sources), 2.5D (elongated sources) and 2D (highly extended in one direction). These 3 types of source geometries were modelled as synthetic cases (Fig. S1, Supplementary Material) in order to show the cartographic signature of each type of source in the four magnetic maps we produced (the magnetic anomaly reduced to the pole, its first order vertical derivative, analytic signal and tilt angle). Both the induced and remanent magnetization were modelled, using respectively the average IGRF of the study area, and a remanent magnetization which we arbitrarily fixed at $\mathrm{D}=-30^{\circ}, \mathrm{I}=50^{\circ}$.
Using these characteristic synthetic signatures, the magnetic compilation maps were interpreted in terms of $3 \mathrm{D} / 2.5 \mathrm{D} / 2 \mathrm{D}$ sources (Figs. 7a-7c) and comments on the remanent character of some anomalies are given in the next section. Overall, the patterns produced by the cartographic repartition of these $3 \mathrm{D} / 2.5 \mathrm{D} / 2 \mathrm{D}$ sources, highlight regional geological domains displaying varied "magnetic textures" (Figs. $7 \mathrm{~d}$ and 8 ) which are also discussed in the following section.

\subsection{Magnetic signature of crustal domains from the new compilation}

The mapping of the different crustal domains of the Bay of Biscay and Pyrenees was previously derived mainly from gravity inversion results and scattered seismic data (Fig. 1, Thinon et al., 2003, Roca et al., 2011; Tugend et al., 2014; 


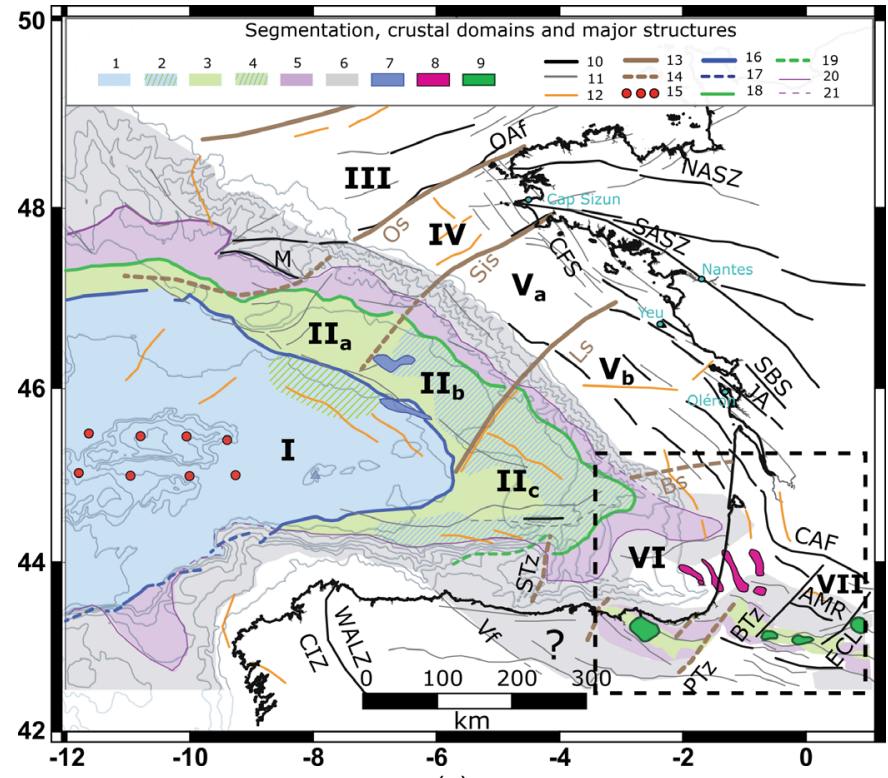

(a)

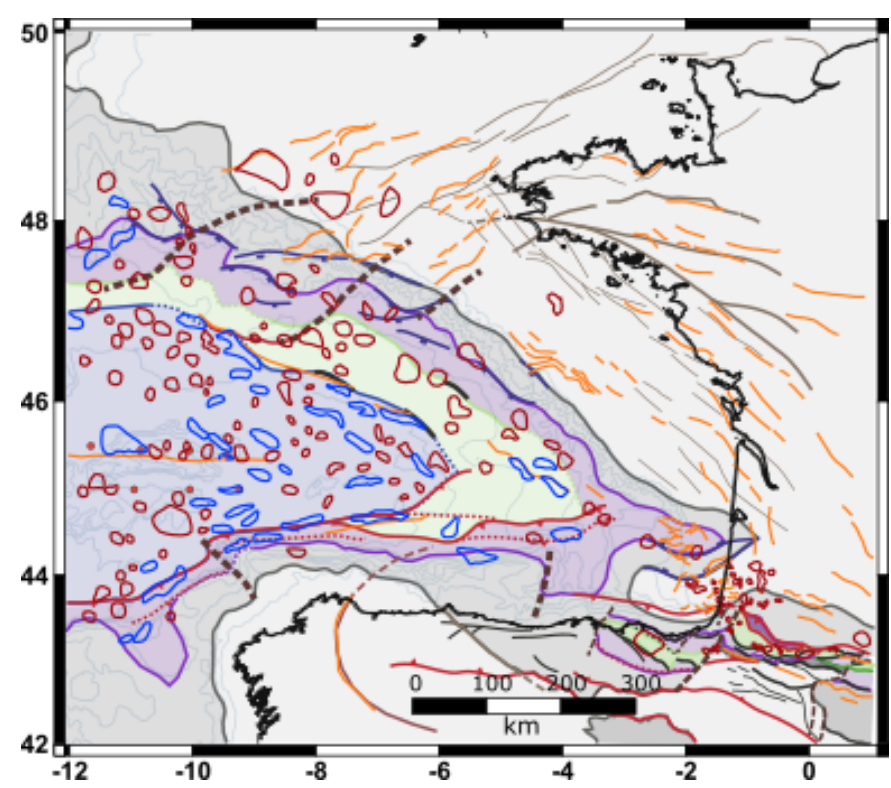

(b)

Ruiz et al., 2017; Cadenas et al., 2018). Our interpretation of the magnetic signal in terms of $3 \mathrm{D} / 2.5 \mathrm{D} / 2 \mathrm{D}$ sources (Fig. $7 \mathrm{~d}$ ) enabled us to characterize the magnetic texture of the different crustal domains (Fig. 1), precise their boundaries and clarify the offshore continuation of major crustal structures mapped on land or from seismic data interpretations.

The interpretation of different magnetic sources reveals lateral variations between the different crustal domains previously identified, but also within them (Fig. 7d): the oceanic abyssal plain (domain I), the OCT (domain II) and the continental domains of the Western Approaches Margin (domain III) and the North and South Armorican Margins (domains IV and $\mathrm{V}$, respectively).
Fig. 8. (A) Magnetic signature superimposed on crustal domains. (B) Segmentation, crustal domains and major structures of the Bay of Biscay region. Crustal domains defined by magnetic signatures: Oceanic (I), Ocean-Continental Transition (IIa, b, c); (III) Western Approaches Margin; (IV) North-Armorican Margin; (V) South Armorican Margin: (a) off south Brittany; (b) off Oléron city; (VI) Aquitaine Margin; (VII) Aquitaine Basin; (1) Oceanic crust; (2) Oceanic crust with underplated serpentinized mantle; (3) OCT with exhumed serpentinized mantle; (4) OCT with exhumed serpentinized mantle with a possible intruded magmatism (with strong magnetic anomalies) (from this study in accordance with Pedreira et al., 2015); (5) hyper-thinned continental crust; (6) thinned continental crust; (7) seamount volcanic edifices on seismic data coinciding to magnetic anomalies; (8) Strong magnetic anomalies associated to subvolcanic rocks (ophites) in the Variscan basement (Taramis well); (9) Strong magnetic anomalies often associated to the exhumed serpentinized mantle or lower crust; (10) Observed major crustal structures with magnetic signatures; (11) Observed major structures; (12) Major magnetic lineament uncorrelated to known structures; (13) Segmentation of continental crustal domains and (14) their extension in the OCT: Ouessant system (Os), Sizun system (Sis) and Loire system (Ls); (15) A34 magnetic anomaly (Seton et al., 2014); (16-17) Observed and supposed boundary of the Biscay oceanic crust; (1819) Observed and supposed boundary between the OCT and the continental domain; (20-21) Observed and supposed boundary between the hyper-thinned and thinned continental domain. Triangle: Ophites sampled by wells (112 ODP leg 12; Taramis); blue names indicate: localities (Cap Sizun, Nantes city, Yeu, Oléron). AMR: Antin-Matourget ridge; BTz: Barlanes transfer Zone; CAF: Celtaquitain flexure (redrawn from the new magnetic compilation); CFS: Concarneau Fault System linked to N140 Kerforne fault; CIZ: Central Iberian Zone; ECL: Eastern Crustal Lineament; JA: Jonzac Anticline; M: Meriadzek Terrace; OAf: Ouessant-Aurigny Fault (Evans 1990, or Iroise Fault according to Le Roy et al., 2011); PTz: Pamplona Transfer Zone; SASZ and NASZ: South and North Armorican Shear Zone; SBS: Saintes-Berbézieux Syncline; STz: Santander Transfer Zone (from Roca et al., 2011); Vf: Ventaniella Fault; WALZ: West Asturian-Leonese Zone. The dashed rectangle correspond to the location of Figure 9.

\subsubsection{Oceanic domain of the Bay of Biscay}

The new magnetic compilation confirms the V-shape of the Bay of Biscay oceanic domain (domain I, Fig. 8) characterized by a series of strong magnetic anomalies (over 100 nT, Fig. 6). This series of high intensity magnetic anomalies terminate against the boundary with the mapped OCT domain of the Western Approaches and Northern Armorican Margins. The boundary between the OCT and oceanic domain is marked by a weak 2D anomaly, which has previously been interpreted as part of the M-series (M4: Sibuet et al., 2004). However, numerous studies now show that the continentward limit of the first oceanic crust cannot be used as an isochron in plate reconstruction (Eagles et al., 2015). Also, as already highlighted by Thinon et al. (2003), no linear anomaly can be interpreted at the emplacement of the M0 pick of Sibuet et al. (2004). Therefore, the previously interpreted isochron magnetic anomalies from the M-series should be reinvestigated in future studies prior to any conclusion. 

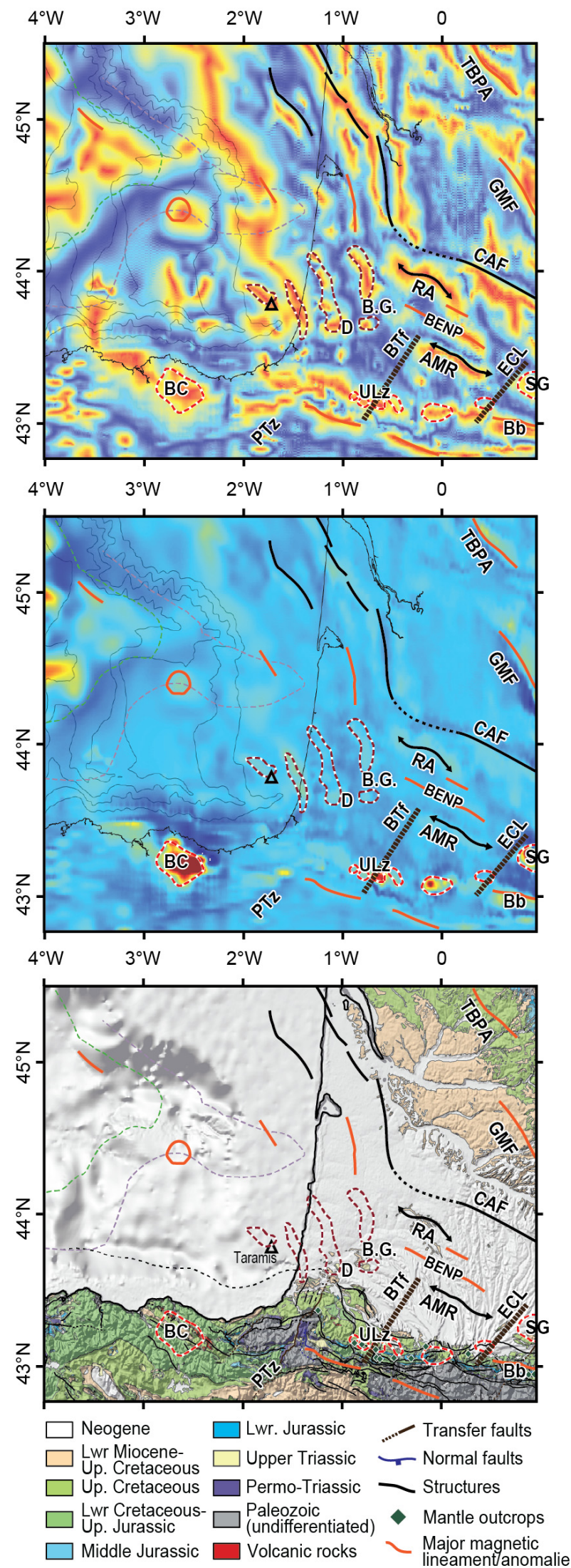

: $\rightleftharpoons$ Series of magnetic anomalies associated to Triassic magmatic rocks =- Magnetic anomalies at the location of mantle outcrops or Cretaceous volcanic rocks
Fig. 9. (A) Tilt angle magnetic map after RTP of the Aquitaine Margin and the Aquitaine Basin (domains VI and VII). (B)Vertical derivative magnetic map after RTP of the Aquitaine Margin and the Aquitaine Basin (domains VI and VII); (C) Simplified geological map of Pyrenees with major structures defined by magnetic signatures; Triangle: eruptive rocks sampled by Taramis well; AMR: AntinMatourget ridge; $\mathrm{Bb}$ : Baronnie Basin; $\mathrm{BC}$ :Basque-Cantabrian anomaly; Pedreira et al., 2007); BG: Bastennes-Gaujacq; BTf: Barlanes transfer fault; CAF: Celtaquitain flexure (redrawn from the new magnetic compilation); D:Dax diapir; ECL: Eastern Crustal Lineament; BENP: Boundary between the European Necking and Proximal domains; GMF: Gavaudun-Monsempron Flexure; PTz: Pamplona Transfer Zone; RA: Roquefort Anticline; TBPA: Tour Blanche-Blessac and Périgueux Anticlines; fault; ULz: Urdach lerzolites; SG: Saint-Gaudens anomaly.

As in previous compilations, an E-W trending linear anomaly is observed in the centre of the Bay of Biscay abyssal plain (Figs. 6 and 7). This anomaly is commonly interpreted as the marine magnetic anomaly 34 young (A34y). This anomaly seems to end at $8^{\circ} \mathrm{W}$ of longitude. To the East, the pattern of the magnetic anomalies changes. There, a series of anomalies oriented NW-SE in the northern part and WSW-ENE in the southern part, is observed and interpreted as delineating the eastern V-shape termination of the unambiguous oceanic domain (at $\sim 6^{\circ} \mathrm{W}$; Fig. $7 \mathrm{~d}$ ). Bathymetric data show that the WSW-ENE trend of magnetic anomalies that characterises the southern domain I is actually located below the present-day slope of the North Iberia Margin, whose morphology is conditioned by the Cenozoic accretionary prism formed during convergence (Fig. 8a). Except for the A34, the number and amplitude of magnetic anomalies appear to be greater east of $8^{\circ} \mathrm{W}$ longitude than to the west.

\subsubsection{Ocean-Continent transitional domain of the Bay of Biscay}

The magnetic signature of the OCT domain of the Bay of Biscay (Domain II in Fig. 8b) is highly variable in the new magnetic compilation, displaying magnetic signatures with three different shapes (2D, 2.5D and 3D, Figs. 6 and 7). To the west, the Western Approaches OCT and the western part of the Armorican OCT (IIa, Fig. 8) are characterized by weak 3D anomalies (Fig. 7), with intensities below 50 nT (total magnetic intensity, Fig. 4). There, the OCT is interpreted as being composed of weakly serpentinized exhumed mantle based on seismic velocities $\left(7.4-7.5 \mathrm{~km} . \mathrm{s}^{-1}\right.$; Thinon et al., 2003). In the eastern part of the Armorican basin four punctual and strong 3D magnetic anomalies greater than $150 \mathrm{nT}$ are observed (IIb, Fig. 8). In this part of the OCT a series of isolated volcanic edifices have previously been identified in the sub-domain IIb (Thinon et al., 2003), one of them coinciding with a 3D magnetic anomaly (Fig. 8). The other strong 3D anomalies visible in sub-domain IIb do not coincide with identifiable shallow crustal structures such as seamount, which could indicate that their sources are deeper. The sub-domains IIb and IIc (Fig. 8) are delimited by a NE-SW alignment of 3D magnetic anomalies with intensities $\sim 100 \mathrm{nT}$ (total magnetic intensity, Fig. 4). The eastern end of the OCT is marked by a series of magnetic anomalies interpreted as resulting from 2.5D sources (Fig. 7) that delineate a V-shape pattern in the 
sub-domain IIc (Figs. 7 and 8). The southern part of this pattern of high intensity magnetic anomalies partly occurs below the present-day slope of the North Iberian Margin.

\subsubsection{Continental domains of the Bay of Biscay passive margins}

The new magnetic compilation on the continental shelf of the North Biscay Margin highlights five continental domains with different magnetic signatures (Fig. 8): the English Channel and the Western Approaches Margin (III), the North Armorican Margin (IV), the South Armorican Margin (Va and $\mathrm{Vb}$ ) and the Aquitaine Margin (VI).

Between the British Isles and France (III), the Western Approaches Margin and the English Channel are mainly characterized by NE-SW linear magnetic anomalies (2D), with intensities of $\sim 50 \mathrm{nT}$. These anomalies extend to the Meriadzek Terrace ( $\mathrm{M}$ in Fig. 8b), a continental spur at the edge of the Western Approaches Margin (Thinon, 1999), where their direction changes to WSW-ENE. This whole set of anomalies coincides with the southern limit of the English Channel Basins and the Ouessant-Aurigny Fault System (OAf; e.g., Evans, 1990; also referred to as Iroise Fault by Le Roy et al., 2011). The OAf would be the southern boundary of the English Channel basins system, called here the Ouessant system (Os).

Off Brittany, the continental shelf of the North Armorican Margin (IV) is characterized by SW-NE linear magnetic anomalies but they are more discontinuous (Fig. 8a) and of lower intensities (of about $20 \mathrm{nT}$, total magnetic intensity, Fig. 4). The boundary of domain IV is mapped along a 2D magnetic anomaly identified in the prolongation of the Ophiolite of Cap-Sizun oceanic suture (Ballèvre et al., 2009), a Variscan structure in-between the Audierne and South Armorican blocks identified onshore at Cap-Sizun (South Brittany coast, Fig. 8b). The identified Sizun system (Sis) is mapped across the continental shelf and delimits the North and the South Armorican Margins.

The northern part of the South Armorican Margin (Va) is weakly magnetic. Rare and weak E-W to NW-SE magnetic anomalies are identified as well as long wavelength magnetic anomalies. No magnetic lineament is clearly identifiable at the location of the major NW-SE structures affecting the Tertiary sedimentary cover and the Variscan basement, such as the Concarneau Fault system (CFS), linked to the N140 Kerforne Fault (Thinon et al., 2009, 2018). Next to the shelf-break and the coastline (off Nantes city), rare NW-SE magnetic lineaments are visible.

The southern part of the South Armorican Margin (Vb) presents linear magnetic anomalies (2D), mainly oriented NWSE, with intensities of $\sim 20 \mathrm{nT}$. Most anomalies coincide with major structures affecting the Variscan basement reactivated during the Pyrenean convergence (e.g., Yeu-Oléron faults; Paquet et al., 2010; Thinon et al., 2018). Onshore, several NWSE magnetic lineaments coincide with major structures such as the Jonzac anticline (JA in Fig. 8b). They are often interrupted and offset, displaying "in relay" geometries. Sometimes, some E-W to ENE-WSW magnetic lineaments are identifiable (off Oleron island). This distribution is similar to that to the Variscan structures mapped in the Armorican Massif, such as the South Armorican Shear Zone (SASZ). Not all faults drawn on the million-scale geological map of France (Chantraine et al., 2003) coincide with a magnetic anomaly. This is particularly true of those identified in the Cenozoic sedimentary cover (Guillocheau et al., 2003; Paquet et al., 2010) questioning their impact at crustal scale.

The number of identified magnetic anomalies in the subdomain $\mathrm{Vb}$ is higher than in the sub-domain Va. The proposed boundary between the sub-domains $\mathrm{Va}$ and $\mathrm{Vb}$, here referred to as the Loire system(Ls) corresponds to (i) an increase of magnetic intensity in the Va sub-domain, and (ii) the presence of a strong magnetic anomaly at the shelf break, which display sigmoid-like or horse-tail like geometry towards the NW. The Loire system (Ls) seems to extend in the OCT domain based on the number of single anomalies in sub-domains IIb and IIc.

In domain (VI), weak 2D (N-S to N160 trending) and 3D magnetic anomalies are observed, most being identified over the Landes High and in the southern part of the Parentis Basin in the $3000 \mathrm{~m}$ compilation (Fig. 5). The boundaries of the domain VI are not clearly outlined by magnetic anomalies. The proposed Bordeaux system(Bs) is defined at the emplacement of a change in magnetic trends (from NW-SE to NNW-SSE) and an increase of magnetic intensities towards the sub-domain $\mathrm{Vb}$. E-W oriented, the Bs is interpreted to delimit the Parentis Basin to the North. In our compiled grids, a series of magnetic anomalies interpreted as related to $3 \mathrm{D}$ sources are observed over the Landes High and western part of the Aquitaine Basin (Fig. 7). Most of, their intensities are over $\sim 100 \mathrm{nT}$ and they are distributed along NW-SE to NNW-SSE trends (Figs. 7-9). The Taramis well, located on top of one of these anomalies (Fig. 9), sampled Triassic to Early Liassic magmatic rocks (Ophites: Curnelle, 1983). In the western Aquitaine Basin, some of these anomalies coincide with salt diapirs (Bastennes-Gaujacq, Dax, Fig. 9), within which ophite bodies are locally embedded (Le Pochat and Thibault, 1977). These spatial correlations and the 3D geometry inferred for the source of these anomalies suggest that these magnetic anomalies could at least partly mark the emplacement of a series of ophite bodies. These intrusions are well known in the Pyrenean-Aquitaine domains, as the result of the Late Triassic-Hettangian rifting stage (Azambre et al., 1987; Rossi et al., 2003).

\subsubsection{Onshore continental domains: Aquitaine Basin, Pyrenees and Basque-Cantabrian Basins}

A series of magnetic anomalies and trends are also observed inland along the Pyrenean orogen, in the Aquitaine and Basque Cantabrian Basins (Fig. 9) and the geometry of the source causing these anomalies is interpreted as being either 2D or 3D (Figs. 7 and 9).

The limit between the Early Cretaceous European necking zone (Figs. 1 and 8, Tugend et al., 2014) and the proximal European margin domain is materialized by a N110 trending anomaly well marked on the Tilt angle map on the northern side of the Pyrenees (Fig. 9a). Further north, another N110 oriented anomaly (CAF in Fig. 9a) can be correlated to the Celtaquitaine Flexure, interpreted as a major Variscan suture between different paleogeographic domains (BRGM et al., 1974; Rolet, 1997). The E-W trending Celtaquitaine Flexure at north of the Aquitaine Basin becomes N-S to NNW-SSE trending further to the west where it seems to join the $\mathrm{N} 140^{\circ}$ 
South-Armorican Yeu-Oléron Variscan faults, also correlated with magnetic trends (Figs. 9). North of the Aquitaine Basin, a series of medium anomalies are observed, roughly parallel to the previously described Celtaquitaine flexure. Those anomalies could partly have indirect relation with far field compressional structures formed during the Pyrenean orogeny (e.g., Jonzac Anticline and Saintes-Barbézieux, La Tour Blanche, Blessac and Périgueux anticlines (TBPA) and the Gavaudun-Monsempron Flexure (GMF) (Platel, 1987, 1996). However, the magnetic signal is most likely originating from Variscan basement heterogeneities such as the NW-SE elongated Saintes-Cognac Carboniferous Basin (Lefort et al., 1997) that favored the localization of later folding. South of the Celtaquitaine flexure, N110 magnetic lineaments with an intensity of $\sim 20 \mathrm{nT}$ are observed and tentatively correlated to the Antin-Maubourguet ridge (AMR, Serrano et al., 2006); and the Roquefort anticline (RA; Cuvillier et al., 1951) (Fig. 9) but most likely to underlying undetermined basement structures.

A series of magnetic anomalies interpreted as related to 3D sources are observed along the Basque-Cantabrian and Pyrenean orogen (Fig. 9). They mostly occur within the interpreted former exhumed mantle domain, now punctually sampled in the Pyrenean orogen and the inverted Basque Cantabrian Basin (Fig. 1, Tugend et al., 2014). Among these magnetic anomalies, the largest one is observed in the Basque Cantabrian Basin, in the Biscay synclinorium, at the location where Cretaceous volcanic rocks are cropping out (Fig. 9; Castanares et al., 1997, 2001; Carracedo et al., 1999). Coherently with this spatial correlation, this anomaly has previously been modelled and interpreted as generated by magmatic intrusions in the lower crust during the Early Cretaceous rifting, later uplifted during the Pyrenean orogeny (Pedreira et al., 2007). Smaller magnetic anomalies are observed in the Cantabrian-Pyrenean junction where granulite and mantle rocks crop out near Ziga (Fig. 9; DeFelipe et al., 2017; Lescoutre et al., 2021). Magnetic anomalies of a similar shape but of slightly higher intensity are also observed in the Pyrenean orogen close to mantle outcrops and/or volcanic rocks (Fig. 9). The N110 trend of magnetic anomalies observed in the Pyrenees is shifted to the north relative to the rift axis of the Basque Cantabrian Basin (Figs. 1 and 9). The Pyrenean rift system is known to be segmented by a series of SSW-NNE to SW-NE transfer zones. Such transfer zones or accommodation zones may delimit different arms of the rift system (i.e., between the Basque-Cantabrian Basin and Western Pyrenees) or segment smaller-scale depocenters (i.e., Arzacq-Mauléon Basin) (e.g., Pedreira et al., 2007; Jammes et al., 2009; Roca et al., 2011; Tugend et al., 2014, 2015b; Masini et al., 2014; Canérot, 2017; Saspiturry et al., 2019; Issautier et al., 2020; Lescoutre and Manatschal, 2020; Lescoutre et al., 2021; Ducoux et al., 2021) but their geometry and lateral extent is not always clear due to successive reactivations. A small-scale shift is observed between the magnetic anomalies of the Mauléon and Chaînons Béarnais areas, possibly related to the transverse fault mapped near the Urdach lherzolite body (ULz in Fig. 9, e.g., Duée et al., 1984; Fortané et al., 1986; Jammes et al., 2009; Debroas et al., 2010; Lagabrielle et al., 2010; Lagabrielle et al., 2019) and interpreted as controlling its exhumation during rifting (Canérot, 2017).
The magnetic anomaly observed at the eastern termination of our magnetic compilation is located near Saint-Gaudens (SG; Fig. 9) and shows an intensity up to $150 \mathrm{nT}$. It is superimposed to a well-known gravity anomaly (Grandjean, 1992), interpreted as generated by a piece of sub-continental mantle (Casas et al., 1997) that was likely previously exhumed in the Baronnies Basin during the Early Cretaceous hyperextension of the Pyrenean rift system (Clerc and Lagabrielle 2014; Tugend et al., 2015b). The strong magnetic anomaly of Saint Gaudens is not incompatible with this assumption; however, forward modelling or an inversion of the magnetic anomaly would be required to confirm this hypothesis. The western end of this anomaly coincides with the Eastern Crustal Lineament (ECL in Fig. 9, Angrand et al., 2018), a transverse structure responsible for the northern shift of the Frontal Pyrenean Thrust in Baronies Basin compared to the Mauléon basin. The mapping of the Eastern Crustal Lineament matches the shift observed between the SG magnetic anomaly and another dipolar magnetic anomaly $(\sim 150 \mathrm{nT})$ emplaced in the North Pyrenean Zone at the easternmost end of the Chaînons Béarnais area. Several ophites and lherzolites bodies crop out in this area (Fig. 9, Casteras et al., 1970) and could possibly contribute to the magnetic signal. The hypothesis of a magnetic anomaly zone across the Oléron-Lourdes-Saint Gaudens band related to volcanic intrusions was proposed by Azambre and Pozzi (1982). Nevertheless, the existence of two sub-continental mantle bodies from either side of the ECL suggest the occurrence of a major transfer zone between two of the North Pyrenean hyperextended basins: Mauléon and Baronnies.

\section{Contribution of the new high resolution magnetic map for geological interpretations}

The analysis of the new magnetic compilation and the different potential field transforms applied to it enabled (1) to precise the limits of the different structural domains of the Bay of Biscay and adjacent continental shelves, (2) to clarify the Bay of Biscay passive margin segmentation and extent of transfer zones, (3) to show lateral variations in the magnetic signature of the OCT and (4) to highlight the location of some structures in the continental crust.

\subsection{Crustal domain boundaries}

The new compilation of magnetic anomaly data improves the identification of magnetic anomalies on the Bay of Biscay and helps clarifying the eastern termination of the unambiguous oceanic domain. The boundary between the oceanic domain and OCT was previously mapped based on seismic data (Thinon et al., 2003) and crustal thickness variations determined from gravity inversion (Tugend et al., 2015a), but the scarcity of seismic data in the oceanic domain west of $6^{\circ} \mathrm{W}$ hampered a robust mapping of this area. The magnetic signature of the north-Iberian OCT and oceanic domains is observed under the present-day slope of the North Iberian Margin (Figs. 7 and 8). This observation is consistent with the underthrusting/proto-subduction induced by the Iberia-Europe convergence previously described (e.g., Alvarez-Marron et al., 1997; Fernandez-Viejo et al., 1998; Gallastegui 2000; Pedreira 
et al., 2007, 2015; Roca et al., 2011; Tugend et al., 2014; Ruiz et al., 2017; Cadenas et al., 2018).

\subsection{Segmentation-transfer zones-inheritance}

Previous authors linked the segmentation observed in the Bay of Biscay to the presence of transfer zones (Fig. 1; Derégnaucourt and Boillot, 1982; Thinon, 1999; Pedreira et al., 2007; Roca et al., 2011; Tugend et al., 2014). Thanks to the new magnetic compilation, we attempted to precise the segmentation of the Bay of Biscay region using variations in the magnetic signal. Changes in the magnetic signal are observed over continental domains (proximal, necking and hyper-thinned crust, Figs. 7 and 8), and in the OCT. Transfer zones played an important role in the segmentation of the margin during rifting (Tugend et al., 2015b), but they also influenced the distribution of the Pyrenean deformation in the OCT (Thinon et al., 2001; Tugend et al., 2014), on the continental shelves and inland (Pedreira et al., 2007; Thinon et al., 2009; Roca et al., 2011). Based on the trend and extent of these transfer zones, as well as on the regional geological knowledge, we propose that these transfer zones partly formed along structures (of crustal scale or possibly lithospheric scale) inherited from the Variscan orogeny as previously suggested by Tugend et al. (2014) for some of them. The effect of these transfer zones is sometimes observed in the OCT where they may locally control the exhumation of the mantle (Ouessant system) or the emplacement of volcanic/magmatic bodies (Sizun system). These transfer zones do not affect the limit between the OCT and the oceanic crust (Fig. 8, Tugend et al., 2014) and hence had no influence on the emplacement of the crust of the oceanic lithosphere.

It should be noted that changes in the architecture observed in the vicinity of these transfer zones are not abrupt but progressive, explaining why they are sometimes referred to as "soft" transfer zones (Roca et al., 2011). At one location (between sub-domains IIb and IIc), an alignment of 3D magnetic anomalies is observed in the OCT in the continuation of the interpreted NE-SW Loire system transfer zone, suggesting that this anomaly is not solely due to inherited continental trends. Because of the nearby presence of volcanic bodies (Thinon et al., 2003), we hypothesize that magmatic intrusions could possibly be emplaced along the transfer zone as suggested in the Gulf of Lion by Canva et al. (2020).

\subsection{Variability of the OCT magnetic signature: magmatic events during propagation?}

Seismic data already enabled the distinction between the northern and southern segment of the Armorican Margin and its OCT (Thinon et al., 2003). In sub-domain IIa (Fig. 8), the basement of the OCT is interpreted as exhumed serpentinized mantle (Thinon et al., 2003; Tugend et al., 2014, 2015a, $2015 \mathrm{~b}$ ) and is directly onlapped by sedimentary sequences (Thinon et al., 2002). In the OCT sub-domain IIb (Fig. 8), an enigmatic and debated seismic unit (seismic unit 3C, Thinon et al., 2003) is observed, and is possibly part of the OCT basement (Gillard et al., 2019). The occurrence of punctual magnetic anomalies of strong intensity in the eastern part of the
Bay of Biscay, partly coinciding with volcanic seamounts, could suggest that the emplacement of exhumed mantle characterizing the OCT of the South Armorican Margin is associated with more magmatic material (IIb, IIc) than in the North Armorican Margin (IIa). In the North Armorican Margin, reflection and refraction seismic data together with the crustal thickness distribution determined from gravity inversion, suggest that magmatism occurs close to the limit between the OCT and the oceanic crust at the end of rifting (Thinon et al., 2003; Tugend et al., 2014). The occurrence of magmatic material intruding the exhumed mantle has also been suggested to characterize the OCT of the eastern part of the North Iberian Margin based on the atypical velocities structure deduced from seismic refraction experiments (Roca et al., 2011; Pedreira et al., 2015; Ruiz et al., 2017). This increasing occurrence of magmatism in the eastern part of Bay of Biscay OCT seems to coincide with the V-shape pattern of high intensity magnetic anomalies observed east of the termination of the oceanic domain (east of $6^{\circ} \mathrm{W}$, Figs. 7 and 8).

Onset of oceanic spreading is unlikely to be synchronous throughout the entire Bay of Biscay and a slightly younger age is suggested for the formation of the eastern part of the Bay of Biscay OCT (Tugend et al., 2014, 2015b; Cadenas et al., 2020), as expected during the propagation of continental breakup. A direct consequence is that the M3 anomaly identified by Sibuet et al. (2004) at the boundary between the OCT and oceanic crust is unlikely to be an isochron. Based on these findings, we interpret the V-shaped pattern of magnetic anomalies as magmatic intrusives and extrusives emplaced at the tip of the Bay of Biscay oceanic propagator during the eastern propagation of continental breakup and tentative localisation of the boundary between the Iberian and European crusts in the future Pyrenees (Tugend et al., 2015b). This failed tentative propagation is supported by the interruption of the continuity of the A34 anomaly east of $8^{\circ} \mathrm{W}$ and the change in the distribution of magnetic anomalies between the western and eastern parts and the northern and southern parts of the oceanic domain (Figs. 8).

\subsection{Contribution of magnetic data to the knowledge of in-depth structures in the continental crust}

The E-W Mesozoic Parentis Basin is not characterized by strong magnetic anomalies. This observation do not favour the hypothesis of a highly heterogeneous crustal basement beneath the Parentis Basin or constituting the Landes High basement, induced by metamorphism and magmatism (Bois et al., 1997). A very thick Mesozoic sedimentary cover as observed in the Parentis Basin could potentially mask the magnetic anomalies, but the sedimentary cover is thin over the Landes High as Paleozoic formations were sampled at a rather shallow depths (Danu well at $1339 \mathrm{~m}$ depth). Rifting in the Parentis Basin was probably not accompanied by a significant magmatism. Over the Landes High and southwestern part of the Aquitaine Basin a series of NNW-SSE trending magnetic anomalies are identified on the $500 \mathrm{~m}$ altitude high-resolution compilation (Fig. 8). They seem to correlate with the emplacement of Triassic-Early Liassic sub-volcanic rocks (Ophites), drilled over the Landes High basement (Curnelle, 1983; Taramis well) and cropping out in salt diapirs (Figs. 9; Bastennes-Gaujacq, Dax, Le Pochat and Thibault, 1977). 
A significant contribution of this compilation relates to the "Celtaquitaine flexure" geometry. Previous mapping indicated a roughly E-W structure with poor signal in its western portion. We rather propose here that this E-W trend, clearly visible in the eastern Aquitaine Basin domain changes to the west to follow the typical NW-SE trend of the Armorican shelf.

\section{Conclusions}

New intermediate resolution onshore-offshore magnetic anomaly maps were compiled in this study and will be available for further studies. They result from the careful compilation of 154 marine and 7 airborne magnetic data sets acquired across the Bay of Biscay and surrounding continental shelves. The resulting regional magnetic compilations at 500 and $3000 \mathrm{~m}$ of elevation have been enhanced by potential field transforms to facilitate the comparison and correlation with known geological features and highlight unknown structures. The main conclusions that result from our study are the following:

- Magnetic anomaly maps and their enhancement by operators such as the analytic signal, tilt angle and vertical derivative are consistent and can be used to improve the structural mapping of the area.

- Some of the magnetic anomalies and magnetic trends observed inland in the Western Pyrenees and the Aquitaine Basin are tentatively correlated to geological structures previously mapped or locally drilled (e.g., Triassic extrusives over the Landes High). Of particular interest is the identification of magnetic trends in the vicinity of the interpreted Celtaquitaine flexure, which are used to refine its mapping from the Aquitaine Basin to the southern Armorican shelf.

- Magnetic trends and changes in the magnetic signature are observed over the Armorican shelf. They seem to occur in the continuation of well-known geological structures previously mapped onshore and in the inner shelf and are tentatively correlated to observed changes in the North Biscay passive margin segmentation.

- Lateral variations of the magnetic signature in the Ocean Continent Transition are also evidenced and are tentatively interpreted as related to magmatism emplaced in the eastern OCT during the aborted plate boundary propagation.

We identified a series of correlations between magnetic anomalies and geological features previously mapped from fieldwork and/or seismic data. However, in order to characterize the geological origin of the magnetic signal, forward modelling and inversions of each identified correlation is required.

\section{Supplementary Material}

Figure S1. Synthetic cases with three source geometries (3D sphere, 2.5D segment and 2D line) for induced $\left(\mathrm{D}=0^{\circ}\right.$, $\left.\mathrm{I}=60^{\circ}\right)$ and remnant magnetization $\left(\mathrm{D}=-30^{\circ}, \mathrm{I}=50^{\circ}\right)$. The first row of maps corresponds to total magnetic intensity map. The second row corresponds to the reduction to the pole, with induced magnetization assumption. The third row corresponds to the vertical derivative. The fourth row corresponds to the vectorial analytic signal or total gradient. The last row corresponds the tilt angle maps.

The Supplementary Material is available at http://www.bsgf.fr/ $10.1051 / \mathrm{bsgf} / 2021048 / \mathrm{olm}$.

Acknowledgments and data availability. This work is part of the Orogen project, cofunded by Total, BRGM and the CNRSINSU, and the BDaéro project funded by the BRGM. We thank SISMER and the Geomagnetism departement of IGN for the magnetic data. We thank the two reviewers, Marta Neres and Odleiv Olesen, as well as the Associate Guest Editor, David Pedreira for their suggestions that improved the manuscript. We thank J.P. Quinquis for beginning the compilation at the BRGM. J. Tugend acknowledges TOTAL SA for her postdoctoral funding. We thank Orogen community for fruitful discussion about the geological background of the study area. Gridded data are available on request to the BRGM (airborne.geophysics@brgm.fr) or the corresponding author (pauline.lemaire3@gmail.com).

Conflicts of interest. The authors declare no conflicts of interest.

\section{References}

Alvarez-Marron J, Rubio E, Torné M. 1997. Subduction-related structures in the North Iberian Margin. Journal of Geophysical Research: Solid Earth 102(B10): 22497-22511.

Angrand P, Ford M, Watts AB. 2018. Lateral variations in foreland flexure of a rifted continental margin: The Aquitaine Basin (SW France). Tectonics 37(2): 430-449.

Ardizone J, Mezcua J, Socías I. 1989. Mapa aeromagnético de España peninsular. Instituto Geográfico Nacional.

Authemayou C, Le Gall B, Caroff M, Bussien Grosjean D. 2019. Wrench-related dome formation and subsequent orogenic syntax bending in a hot orogen (Variscan Ibero-Armorican Arc, the Ouessant Island, France). Tectonics 38(10): 3563-3585.

Ayarza P, Martínez Catalán JR, Alvarez-Marrón J, Zeyen H, Juhlin C. 2004. Geophysical constraints on the deep structure of a limited ocean-continent subduction zone at the North Iberian Margin. Tectonics 23(1). https://doi.org/10.1029/2002TC001487.

Azambre B, Pozzi JP. 1982. Étude du magnétisme des roches éruptives de la région d'Arette (Pyrénées Atlantiques): préliminaire à l'analyse de l'évolution des contraintes regionales. Bulletin de la Société Géologique de France 7(2): 255-263.

Azambre B, Rossy M, Lago M. 1987. Caractéristiques petrologiques des dolerites tholeiitiques d'age triasique (ophites) du domaine pyrénéen. Bulletin de minéralogie 110(4): 379-396.

Bacon M, Gray F, Matthews DH. 1969. Crustal structure studies in the Bay of Biscay. Earth Planet. Sci. Lett. 6: 377.

Ballèvre M, Bosse V, Ducassou C, Pitra P. 2009. Palaeozoic history of the Armorican Massif: Models for the tectonic evolution of the suture zones. Comptes Rendus Géoscience 341(2-3): 174-201.

Ballèvre M, Catalán JRM, López-Carmona A, Pitra P, Abati J, Fernández RD, et al. 2014. Correlation of the nappe stack in the Ibero-Armorican arc across the Bay of Biscay: A joint FrenchSpanish project. Geological Society, London, Special Publications 405(1): 77-113.

Baranov V. 1957. A new method for interpretation of aeromagnetic maps: Pseudo-gravimetric anomalies. Geophysics 22: 359-382. https://doi.org/10.1190/1.1438369. 
Barbier F, Le Pichon X, Duvergé J. 1986. Structure profonde la marge Nord-Gascogne: Implications sur le mécanisme de rifting et de formation de la marge continentale. Bull. Cent. Recherches et Explor. Prod. Elf Aquitaine 10(1): 105-121.

Barnett-Moore N, Hosseinpour M, Maus S. 2016. Assessing discrepancies between previous plate kinematic models of Mesozoic Iberia and their constraints. Tectonics 35: 1843-1862. https://doi.org/10.1002/2015TC004019.

Barnett-Moore N, Font E, Neres M. 2017. A reply to the comment on "Assessing discrepancies between previous plate kinematic models of Mesozoic Iberia and their constraints" by Barnett-Moore et al. Tectonics 36. https://doi.org/10.1002/2017TC004760.

Biteau JJ, Le Marrec A, Le Vot M, Masset JM. 2006. The Aquitaine Basin. Petroleum Geoscience 12(3): 247-273.

Boillot G. 1984. Les marges continentales actuelles et fossiles autour de la France. Elsevier Masson.

Boillot G, Dupeuble PA, Malod J. 1979. Subduction and tectonics on the continental margin off northern Spain. Marine Geology 32 (1-2): 53-70.

Bois C, Gabriel O, Lefort JP, Rolet J, Brunet F. 1997. Geologic contribution of the Bay of Biscay deep seismic survey: A summary of the main scientific results: A discussion of the open questions.

BRGM, Société Elf Recherche, Société ESSO de recherche et Exploitation du Pétrole Société Nationale des Pétroles d'Aquitaine. 1974. Géologie du Bassin d'Aquitaine, 29 encl. Orléans : BRGM (in French).

Cadenas P, Fernández-Viejo G, Pulgar JA, Tugend J, Manatschal G, Minshull TA. 2018. Constraints imposed by rift inheritance on the compressional reactivation of a hyperextended margin: Mapping rift domains in the North Iberian Margin and in the Cantabrian Mountains. Tectonics 37(3): 758-785.

Cadenas P, Manatschal G, Fernández-Viejo G. 2019. Structural fingerprints of polyphase extension: Formation and spatial overlap of hyperextended rift basins at the southern Bay of Biscay. In: EGUGA1, 2202.

Cadenas P, Manatschal G, Fernández-Viejo G. 2020. Unravelling the architecture and evolution of the inverted multi-stage North Iberian-Bay of Biscay rift. Gondwana Research 88: 67-87.

Calvet M, Sylvander M, Margerin L, Villaseñor A. 2013. Spatial variations of seismic attenuation and heterogeneity in the Pyrenees: Coda Q and peak delay time analysis. Tectonophysics 608, 428439.

Cande SC, Kristoffersen Y. 1977. Late Cretaceous magnetic anomalies in the north Atlantic. Earth Planet. Sci. Lett. 35: 215-224.

Canérot J. 2017. The pull apart-type Tardets-Mauléon Basin: A key to understand the formation of the Pyrenees. Bulletin Société géologique de France 188(6): 35.

Canva A, Thinon I, Peyrefitte A, Couëffé R, Maillard A, Jolivet L, et al. 2020. The Catalan magnetic anomaly: Its significance for the crustal structure of the Gulf of Lion passive margin and relationship to the Catalan Transfer Zone. Marine and Petroleum Geology 113: 104174.

Carracedo M, Larrea FJ, Alonso A. 1999. Estructura y organización de las coladas submarinas: características de las lavas almohadilladas de edad cretácica que afloran en la Cordillera VascoCantábrica, Estud. Geológicos 55(5-6): 45-53.

Casas A, Kearey P, Rivero L, Adam CR. 1997. Gravity anomaly map of the Pyrenean region and a comparison of the deep geological structure of the western and eastern Pyrenees. Earth and Planetary Science Letters 150(1-2): 65-78.

Castanares LM, Robles S, Vicente Bravo JC. 1997. Distribution estratigrafica de los episodios volcanicos submarinos del Albiense-
Santoniense en la Cuenca Vasca (sector Gernika-Plentzia, Bizkaia). Geogaceta 22: 43-46.

Castanares LM, Robles S, Gimeno D, Vicente Bravo JC. 2001. The Submarine Volcanic System of the Errigoiti Formation (AlbianSantonian of the Basque-Cantabrian Basin, Northern Spain): Stratigraphic framework, facies, and sequences. J. Sediment. Res. 71: 318-333. https://doi.org/10.1306/080700710318.

Casteras M, Souquet P, Paris JP. 1970. Carte géologique de la France à 1/50 000 : Larrau. Bureau de Recherches Géologiques et Minières.

Chantraine J, Autran A, Cavelier C. 2003. Carte géologique de la France au 1/1000000- $6^{\mathrm{e}}$ édition révisée. Orléans: Bureau de Recherches Géologiques et Minières (BRGM).

Clerc C, Lagabrielle Y. 2014. Thermal control on the modes of crustal thinning leading to mantle exhumation: Insights from the Cretaceous Pyrenean hot paleomargins. Tectonics 33(7): 1340 1359.

Cochelin B, Chardon D, Denèle Y, Gumiaux C, Le Bayon B. 2017. Vertical strain partitioning in hot Variscan crust: Syn-convergence escape of the Pyrenees in the Iberian-Armorican syntax. Bulletin de la Société géologique de France 188(6): 39.

Cooper GRJ, Cowan DR. 2005. Differential reduction to the pole. Computer Geoscience 31: 989-999. https://doi.org/10.1016/j. cageo.2005.02.005.

Curnelle R. 1983. Evolution structuro-sédimentaire du Trias et de 1'Infra-Lias d'Aquitaine. Bulletin des Centres de recherches exploration-production Elf-Aquitaine 7(1): 69-99.

Cuvillier J, Dupouy-Camet J, Sacal V. 1951. L'anticlinal de Roquefort-des-Landes et les pointements cretaces de CreonSaint-Julien. Bulletin de la Société Géologique de France S6-I(7): 553-584. https://doi.org/10.2113/gssgfbull.S6-I.7.553.

Dampney CNG. 1969. The equivalent source technique. Geophysics 34: 39-53.

Debroas E-J, Canérot J, Bilotte M. 2010. Les Brèches d'Urdach, témoins de l'exhumation du manteau pyrénéen dans un escarpement de faille vraconnien-cénomanien inférieur (zone nordpyrénéenne, Pyrénées-Atlantiques, France). Géologie de la France 2: 53-64.

DeFelipe I, Pedreira D, Pulgar JA, Iriarte E, Mendia M. 2017. Mantle exhumation and metamorphism in the Basque-Cantabrian Basin (N Spain). Stable and clumped isotopic analysis in carbonates and comparison with ophicalcites in the North-Pyrenean Zone (Urdach and Lherz). Geochemistry, Geophysics, Geosystems 18: 631-652.

Derégnaucourt D, Boillot G. 1982. Structure géologique du golfe de Gascogne. Bulletin BRGM 2: 149-178.

D'Errico JR. 2006. Understanding gridfit, vol.55, pp. 70-83. Available from http://www.mathworks.com/matlabcentral/fileex change/loadFile.do.

Druet M, Muñoz-Martín A, Granja-Bruña JL, Carbó-Gorosabel A, Acosta J, Llanes P, et al. 2018. Crustal structure and continentocean boundary along the Galicia continental margin (NW Iberia): Insights from combined gravity and seismic interpretation. Tectonics 37(5): 1576-1604.

Ducoux M, Masini M, Tugend J, Gomez-Romeu J, Calassou S. 2021. Basement-decoupled hyperextension rifting: The tectono-stratigraphic record of the salt-rich Pyrenean necking zone (Arzacq Basin, SW France). GSA Bulletin. https://doi.org/10.1130/B35974.1.

Duée G, Lagabrielle Y, Coutelle A, Fortané A. 1984, Les lherzolites associées aux Chaînons Béarnais (Pyrénées Occidentales) : mise à l'affleurement anté-dogger et resédimentation albo-cénomanienne. C. R. Acad. Sci. Ser. II 299: 1205-1209.

Eagles G, Pérez-Díaz L, Scarselli N. 2015. Getting over continent ocean boundaries. Earth-Science Reviews 151: 244-265. 
Etheve N, Mohn G, Frizon de Lamotte D, Roca E, Tugend J, GómezRomeu J. 2018. Extreme Mesozoic crustal thinning in the eastern Iberia Margin: The example of the Columbrets Basin (Valencia Trough). Tectonics 37(2): 636-662.

Evans CDR. 1990. United Kingdom offshore regional report: The geology of the Western English Channel and its Western Approaches. London: British Geological Survey, NERC, HMSO, $94 \mathrm{p}$.

Fernandez-Viejo G, Gallart J, Pulgar JA, Gallastegui J, Danobeitia JJ, Cordoba D. 1998. Crustal transition between continental and oceanic domains along the North Iberian Margin from wide angle seismic and gravity data. Geophysical Research Letters 25: 42494252.

Ferrer O, Roca E, Benjumea B, Muñoz JA, Ellouz N, Marconi Team. 2008. The deep seismic reflection MARCONI-3 profile: Role of extensional Mesozoic structure during the Pyrenean contractional deformation at the eastern part of the Bay of Biscay. Marine and Petroleum Geology 25(8): 714-730.

Ferrer O, Roca E, Jackson MPA, Muñoz JA. 2009. Effects of Pyrenean contraction on salt structures of the offshore Parentis Basin (Bay of Biscay). Trabajos de geología (29).

Fortané A, Duée G, Lagabrielle Y, Coutelle A. 1986. Lherzolites and the Western "Chaînons Béarnais" (French Pyrénées): Structural and paleogeographical pattern. Tectonophysics 129: 81-98.

Gallastegui J. 2000. Estructura cortical de la cordillera y margen continental cantábricos: perfiles ESCI-N. Trabajos de Geología (22): 3-234.

Gallastegui J, Pulgar JA, Gallart J. 2002. Initiation of an active margin at the North Iberian continent-ocean transition. Tectonics 21(4): $15-1$.

García-Senz J, Pedrera A, Ayala C, Ruiz-Constán A, Robador A, Rodríguez-Fernández LR. 2020. Inversion of the north Iberian hyperextended margin: the role of exhumed mantle indentation during continental collision. Geological Society, London, Special Publications 490(1): 177-198.

Gariel O, Bois C, Curnelle R, Lefort JP, Rolet J. 1997. The ECORS Bay of Biscay deep seismic survey. Geological framework and overall presentation of the work. Mémoires de la Société géologique de France (1833) 171: 7-19.

Gillard M, Tugend J, Müntener O, Manatschal G, Karner GD, Autin J, et al. 2019. The role of serpentinization and magmatism in the formation of decoupling interfaces at magma-poor rifted margins. Earth-Science Reviews 196(June): 102882. https://doi.org/ 10.1016/j.earscirev.2019.102882.

Girardeau J, Dubuisson G, Mercier JCC. 1986. Cinématique de mise en place des ophiolites et nappes crystallophiliennes du Limousin, Ouest du Massif Central francais. Bulletin de la Société géologique de France 2(5): 849-860.

Gee JS, Kent DV. 2007. Source of oceanic magnetic anomalies and the geomagnetic polarity time scale.

Geosoft. 2013. Getting Started with montaj GridKnit, Extension for Oasis Montaj v.8.0, Geosoft Corporation.

Graciansky PC, Poag CW. 1981. Geology history of Goban Spur, northwest europe continental margin. In: Bailey GB, ed. Initial Reports of the Deep Sea Drilling Profect, vol. 80, pp. 1187-1216. Washington: U.S. Government Printing Office.

Grandjean G. 1992. Études des structures crustales dans une portion de la chaîne et de leur relation avec les bassins sédimentaires: application aux Pyrénées Occidentales au travers du projet ECORS-arzacq-Pyrénées. Doctoral dissertation, PhD thesis, Université de Montpellier III, Montpellier, France.

Grau G, Montadert L, Delteil R, Winnock E. 1973. Structure of the european continental margin between Portugal and Ireland, from seismic data. Tectonophysics 20: 319-339.
Guillocheau F, Brault N, Thomas E, Barbarand J, Bonnet S, Bourquin $\mathrm{S}$, et al. 2003. Histoire géologique du Massif Armoricain depuis $140 \mathrm{Ma}$ (Crétacé-Actuel). Bulletin d'Information des Géologues du Bassin de Paris 40: 13-28.

Issautier B, Nicolas S, Serrano O. 2020. Role of structural inheritance and salt tectonics in the formation of pseudosymmetric continental rifts on the european margin of the hyperextended Mauléon Basin (Early Cretaceous Arzacq and Tartas Basins). Marine and Petroleum Geology 104395.

Jammes S, Manatschal G, Lavier L, Masini E. 2009. Tectonosedimentary evolution related to extreme crustal thinning ahead of a propagating ocean: Example of the western Pyrenees. Tectonics 28. https://doi.org/10.1029/2008TC002406.

Jammes S, Manatschal G, Lavier L. 2010a. Interaction between prerift salt and detachment faulting in hyperextended rift systems: The example of the Parentis and Mauléon Basins (Bay of Biscay and western Pyrenees). AAPG Bulletin 94(7): 957-975.

Jammes S, Tiberi C, Manatschal G. 2010b. 3D architecture of a complex transcurrent rift system: the example of the Bay of BiscayWestern Pyrenees. Tectonophysics 489(1-4): 210-226.

Le Borgne E, Le Mouël JL. 1969. La nouvelle carte magnétique de la France. Ann. Inst. Phys. Globe 35: 197-224.

Le Borgne E, Le Mouël J-L, Le Pichon X. 1971. Aeromagnetic survey of South-Western. Earth and Planetary Science Letters 12: $287-$ 299. https://doi.org/10.1016/0012-821X(71)90213-5.

Le Pochat G, Thibault C. 1977. Notice explicative et carte géologique de la France à 1/50 000e. Bull. B.R.G.M. 26.

Le Roy P, Gracia-Garay C, Guennoc P, Bourillet JF, Reynaud JY, Thinon I, et al. 2011. Cenozoic tectonics of the Western Approaches Channel Basins and its control of local drainage systems. Bulletin de la Société Géologique de France 182(5): 451-463.

Le Suave R. 1997. ZEEGASC2 cruise, RV L'Atalante. https://doi.org/ 10.17600/97010070.

Lagabrielle Y, Labaume P, de Saint Blanquat M. 2010. Mantle exhumation, crustal denudation, and gravity tectonics during Cretaceous rifting in the Pyrenean realm (SW Europe): Insights from the geological setting of the lherzolite bodies. Tectonics 29(4).

Lagabrielle Y, Asti R, Fourcade S, Corre B, Poujol M, Uzel J, et al. 2019. Mantle exhumation at magma-poor passive continental margins. Part I. 3D architecture and metasomatic evolution of a fossil exhumed mantle domain (Urdach lherzolite, north-western Pyrenees, France) [Exhumation du manteau au pied des marges passives pauvres en magma. Partie 1 . Architecture 3D et évolution métasomatique du domaine fossile à manteau exhumé (lherzolite d'Urdach, Pyrénées NW, France)]. Bulletin de la Société Géologique de France 190(1).

Larrasoaña JC, Parés JM, Pueyo EL. 2003. Stable Eocene magnetization carried by magnetite and iron sulphides in marine marls (Pamplona-Arguis Formation, southern Pyrenees, northern Spain). Studia geophysica et geodaetica 47(2): 237-254.

Laughton AS, Berggren WA, Benson R, Davies TA, Franz U, Musich L, et al. 1972a. Initial reports of the deep sea drilling project 118 , vol. 12, pp. 673-751.

Laughton AS, Berggren WA, Benson R, Davies TA, Franz U, Musich L, et al. $1972 \mathrm{~b}$. Initial reports of the deep sea drilling project site 119, vol. 12, pp. 753-901.

Lefort JP, Bois C, Liewig N, Peucat JJ, Agarwal B. 1997. Contribution of the ECORS Bay of Biscay deep seismic profile to the location of the southern Variscan front beneath the Aquitaine Basin (France). Mémoires de la Société géologique de France (1833) 171: 79-96.

Lescoutre R, Manatschal G. 2020. Role of rift-inheritance and segmentation for orogenic evolution: example from the PyreneanCantabrian system. BSGF-Earth Sciences Bulletin 191: 18. 
Lescoutre R, Manatschal G, Muñoz JA. 2021 Nature, origin and evolution of the Pyrenean-Cantabrian junction. Tectonics 40. https://doi.org/10.1029/2020TC006134.

Lesur V, Hamoudi M, Choi Y, Dyment J, Thébault E. 2016. Building the second version of the World Digital Magnetic Anomaly Map (WDMAM). Earth Planets Space 68. https://doi.org/10.1186/ s40623-016-0404-6.

Luyendyk APJ. 1997. Processing of airborne magnetic data. AGSO Journal of Australian Geology and Geophysics 17: 31-38.

Maillet P. 1977. Étude Géochimique de quelques séries spilitiques du massif armoricain: Implications géotectoniques. Doctoral dissertation, Université de Rennes.

Masini E, Manatschal G, Tugend J, Mohn G, Flament JM. 2014. The tectono-sedimentary evolution of a hyper-extended rift basin: the example of the Arzacq-Mauléon rift system (Western Pyrenees, SW France). International Journal of Earth Sciences 103(6): 1569-1596.

Matte P. 2001. The Variscan collage and orogeny (480-290 Ma) and the tectonic definition of the Armorica microplate: a review. Terra Nova 13(2): 122-128.

Matte P, Ribeiro A. 1975. Forme et orientation de l'ellipsoide de déformation dans la virgation hercynienne de Galice. Relations avec le plissement et hypothèses sur la génèse de l'arc Iberoaméricain. C. R. Seances Acad. Sci. Paris 280: 2825-2828.

Mauriaud P. 1987. La tectonique salifère d'Aquitaine. Le bassin d'Aquitaine. Pétrole et techniques (335): 38-41.

Maus S, Barckhausen U, Berkenbosch H, Bournas N, Brozena J, Childers V, et al. 2009. EMAG2: A 2-arc min resolution Earth Magnetic Anomaly Grid compiled from satellite, airborne, and marine magnetic measurements. Geochemistry, Geophysics, Geosystems 10: Q08005. https://doi.org/10.1029/2009GC002471.

Mercier JC, Girardeau J, Prinzhoffer A, Dubuisson G. 1985. Les complexes ophiolitiques du Limousin: structuren pétrologie et géochimie. Doc. Bur. Rech. Géol. Min. 95(3): 35-48.

Meyer B, Chulliat A, Saltus R. 2017. Derivation and Error Analysis of the Earth Magnetic Anomaly Grid at 2 arc min Resolution Version 3 (EMAG2v3). Geochemistry, Geophysics, Geosystems 18: 45224537. https://doi.org/10.1002/2017GC007280.

Miller HG, Singh V. 1994. Potential field tilt-A new concept for location of potential field sources. Journal of Applied Geophysics 32: 213-217.

Montadert L, Winnock E, Delteil JR, Grau G. 1974. Continental Margins of Galicia-Portugal and Bay of Biscay. In: Burk CA, Drake CL, eds. The Geology of Continental margins, vol. I. Paris: Springer-Verlag, pp. 323-341.

Montadert L, Roberts DG, De Charpal O, Guennoc P. 1979. Rifting and subsidence of the northern continental margin of the Bay of Biscay. In: Usher JL, ed. Initial Reports of the Deep Sea Drilling Project, vol. 48, pp. 1025-1060. Washington.

Montigny R, Allegre C. 1974. In search of lost oceans-eclogite of vendee in old oceanic crust. Comptes rendus hebdomadaires des sciences de l'académie des sciences serie D 279(7): 543-545.

Montigny R, Azambre B, Rossy M, Thuizat R. 1986. K-Ar study of cretaceous magmatism and metamorphism in the Pyrenees: Age and length of rotation of the Iberian Peninsula. Tectonophysics 129: 257-273.

Mouthereau F, Filleaudeau PY, Vacherat A, Pik R, Lacombe O, Fellin MG, et al. 2014. Placing limits to shortening evolution in the Pyrenees: Role of margin architecture and implications for the Iberia/Europe convergence. Tectonics 33(12): 2283-2314.

Neres M, Terrinha P, Custódio S, Silva SM, Luis J, Miranda JM. 2018. Geophysical evidence for a magmatic intrusion in the ocean-continent transition of the SW Iberia Margin. Tectonophysics 744: 118-133.
Nirrengarten M, Manatschal G, Tugend J, Kusznir NJ, Sauter D. 2017. Nature and origin of the J-magnetic anomaly offshore IberiaNewfoundland: implications for plate reconstructions. Terra Nova 29(1): 20-28.

Nirrengarten M, Manatschal G, Tugend J, Kusznir N, Sauter D. 2018. Kinematic evolution of the southern North Atlantic: Implications for the formation of hyperextended rift systems: Kinematic of hyperextended rift systems. Tectonics. https://doi.org/10.1002/ 2017 TC004495.

Oliveira Jr VC, Barbosa VCF, Uieda L. 2013. Polynomial equivalent layer. Geophysics 78: G1-G13. https://doi.org/10.1190/geo20120196.1.

Olivet JL. 1996. La cinématique de la plaque ibérique. Bulletin des centres de recherches exploration-production Elf-Aquitaine 20(1): 131-195.

Paquet F, Menier D, Estournès G, Bourillet JF, Leroy P, Guillocheau F. 2010. Buried fluvial incisions as a record of Middle-Late Miocene eustasy fall on the Armorican Shelf (Bay of Biscay, France). Marine Geology 268(1-4): 137-151.

Pautot G. 1992. ZEE GASCOGNE cruise, RV L'Atlante. https://doi. org/10.17600/92000711.

Pedreira D, Pulgar JA, Gallart J, Torné M. 2007. Three-dimensional gravity and magnetic modeling of crustal indentation and wedging in the western Pyrenees-Cantabrian Mountains. Journal of Geophysical Research: Solid Earth 112(B12).

Pedreira D, Afonso JC, Pulgar JA, Gallastegui J, Carballo A, Fernandez M, et al. 2015. Geophysical-petrological modeling of the lithosphere beneath the Cantabrian Mountains and the NorthIberian Margin: Geodynamic implications. Lithos 230: 46-68.

Platel JP. 1987. Le Crétacé supérieur de la plate-forme septentrionale du Bassin d'Aquitaine: stratigraphie et évolution géodynamique. Doctoral dissertation, Bordeaux 3.

Platel JP. 1996. Stratigraphie, sédimentologie et évolution géodynamique de la plate-forme carbonatée du Crétacé supérieur du nord du bassin d'Aquitaine. Géologie de la France (4): 33-58.

Razin P. 1989. Évolution tecto-sédimentaire alpine des Pyrénées Basques à l'Ouest de la transformante de Pamplona(province du Labourd). Doctoral dissertation.

RocaE, MuñozJ.A, FerrerO, EllouzN. 2011. The role of the Bay ofBiscay Mesozoic extensional structure in the configuration of the Pyrenean orogen: Constraints from the MARCONI deep seismic reflection survey. Tectonics 30. https://doi.org/10.1029/2010TC002735.

Rocher M, Lacombe O, Angelier J, Deffontaines B, Verdier F. 2000. Cenozoic folding and faulting in the south Aquitaine Basin (France): Insights from combined structural and paleostress analyses. Journal of Structural Geology 22(5): 627-645.

Roest WR, Verhoef J, Pilkington M. 1992. Magnetic interpretation using the 3-D analytic signal. Geophysics 57: 116-125. https://doi. org/10.1190/1.1443174.

Rolet J. 1997. The concealed basement of Aquitaine. Mémoires de la Société géologique de France (1833) 171: 115-141.

Rosenbaum G, Lister GS, Duboz C. 2002. Relative motions of Africa, Iberia and Europe during Alpine orogeny. Tectonophysics 359 (1-2): 117-129.

Rossi P, Cocherie A, Fanning CM, Ternet Y. 2003. Datation U/ Pb sur zircons des dolérites tholéiitiques pyrénéennes (ophites) à la limite Trias-Jurassique et relations avec les tufs volcaniques dits «infraliasiques » nord-pyrénéens. Comptes Rendus Geoscience 335(15): 1071-1080.

Ruiz M, Díaz J, Pedreira D, Gallart J, Pulgar JA. 2017. Crustal structure of the North Iberian continental margin from seismic refraction/wide-angle reflection profiles. Tectonophysics 717: 65-82. 
Santallier D. 1981. Les roches métamorphiques du Bas-Limousin, Massif central (France). Thèse d'Etat, Orléans, $340 \mathrm{p}$.

Saspiturry N, Razin P, Baudin T, Serrano O, Issautier B, Lasseur E, et al. 2019. Symmetry vs. asymmetry of a hyper-thinned rift: Example of the Mauléon Basin (Western Pyrenees, France). Marine and Petroleum Geology 104: 86-105. https://doi.org/ 10.1016/j.marpetgeo.2019.03.031.

Serrano O, Delmas J, Hanot F, Vially R, Herbin JP, Houel B, et al. 2006. Le Bassin d'Aquitaine : valorisation des données sismiques, cartographie structurale et potentiel pétrolier. Ed. BRGM, 2 volumes, $245 \mathrm{p}, 142$ figures, 17tableaux, 17 annexes.

Seton M, Whittaker J, Wessel P, Müller RD, DeMets C, Merkouriev S, et al. 2014. Community infrastructure and repository for marine magnetic identifications. Geochemistry, Geophysics, Geosystems 5 (4): 1629-1641.

Sibuet JC, Collette BJ. 1991. Triple junctions of Bay of Biscay and North Atlantic: New constraints on the kinematic evolution. Geology 19(5): 522-525.

Sibuet JC, Srivastava SP, Spakman W. 2004. Pyrenean orogeny and plate kinematics. Journal of Geophysical Research: Solid Earth 109(B8).

Srivastava SP, Roest WR, Kovacs LC, Oakey G, Levesque S, Verhoef J, et al. 1990. Motion of Iberia since the Late Jurassic: Results from detailed aeromagnetic measurements in the Newfoundland Basin. Tectonophysics 184(3-4): 229-260.

Srivastava SP, Sibuet JC, Cande S, Roest WR, Reid ID. 2000. Magnetic evidence for slow seafloor spreading during the formation of the Newfoundland and Iberian Margins. Earth and Planetary Science Letters 182(1): 61-76.

Thébault E, Finlay CC, Beggan CD, Alken P, Aubert J, Barrois O, et al. 2015. International Geomagnetic Reference Field: The 12th Generation. Earth Planets Space 67. https://doi.org/10.1186/ s40623-015-0228-9.

Thinon I. 1999. Structure profonde de la marge nord-Gascogne et du Bassin Armoricain. Thèse de doctorat, Brest.

Thinon I, Fidalgo-González L, Réhault J-P, Olivet J-L. 2001. Déformations pyrénéennes dans le golfe de Gascogne. Comptes Rendus de l'Académie des Sciences - Series IIA - Earth and Planetary Science 332: 561-568. https://doi.org/10.1016/S1251-8050(01)01576-2.

Thinon I, Réhault JP, Fidalgo-Gonzalez L. 2002 The syn-rift sedimentary cover of the North Biscay Margin (Bay of Biscay): From new reflection seismic data. Bulletin de la Société Géologique de France 173(6): 515-522.

Thinon I, Matias L, Réhault JP, Hirn A, Fidalgo-GonzÁlez L, Avedik F. 2003. Deep structure of the Armorican Basin (Bay of Biscay): A review of Norgasis seismic reflection and refraction data. Journal of the Geological Society 160: 99-116. https://doi.org/10.1144/ 0016-764901-103.

Thinon I, Menier D, Guennoc P, Proust J-N. 2009. Carte géologique de la France à $1 / 250000$ de la marge continentale. Lorient, Bretagne Sud: Éditions BRGM-CNRS.

Thinon I, Proust JN, Nalpas T, Elongo V, Vérité J. 2018. Structure of the Mesozoic sedimentary cover of the North Aquitaine continental shelf-New results from offshore and onshore observations in the Charente region (France). In: RST Congress Talk.

Tikhonov AN, Arsenin VY. 1977 Solutions of Ill-Posed Problems. Washington DC: Winston and Sons.

Triboulet C, Audren C. 1985. Continuous reactions between biotite, garnet, staurolite, kyanite-sillimanite-andalusite and P-T-timedeformation path in micaschists from the estuary of the river Vilaine, South Brittany, France. Journal of Metamorphic Geology 3 (1): 91-105.

Tugend J, Manatschal G, Kusznir NJ, Masini E, Mohn G, Thinon I. 2014. Formation and deformation of hyperextended rift systems: Insights from rift domain mapping in the Bay of Biscay-Pyrenees. Tectonics 33: 1239-1276. https://doi.org/10.1002/ 2014TC003529.

Tugend J, Manatschal G, Kusznir NJ, Masini E. 2015a. Characterizing and identifying structural domains at rifted continental margins: application to the Bay of Biscay Margins and its Western Pyrenean fossil remnants. Geological Society, London, Special Publications 413: 171-203. https://doi.org/10.1144/SP413.3.

Tugend J, Manatschal G, Kusznir NJ. 2015b. Spatial and temporal evolution of hyperextended rift systems: Implication for the nature, kinematics, and timing of the Iberian-European plate boundary. Geology 43(1): 15-18.

Verhoef J, Roest WR, Macnab R, Arkani-Hamed J, Members of the Project Team. 1996. Magnetic anomalies of the Arctic and North Atlantic Oceans and adjacent land areas; GSC Open File 3125, Parts a and b (CD-ROM and project report). Dartmouth, NS: Geological Survey of Canada.

Williams CA. 1975. Sea-floor spreading in the Bay of Biscay and its relationship to the North Atlantic. Earth and Planetary Science Letters 24(3): 440-456.

Yang P, Welford JK, Peace AL, Hobbs R. 2020. Investigating the Goban Spur rifted continental margin, offshore Ireland, through integration of new seismic reflection and potential.

Ziegler PA. 1987. Late Cretaceous and Cenozoic intra-plate compressional deformations in the Alpine foreland-A geodynamic model. Tectonophysics 137(1-4): 389-420.

Cite this article as: Le Maire P, Thinon I, Tugend J, Issautier B, Martelet G, Paquet F, Proust J-N, Nalpas T, Peyrefitte A, Canva A. 2021. New Magnetic compilation and interpretation of the Bay of Biscay and surrounding continental shelves, BSGF-Earth Sciences Bulletin 192: 58. 